\title{
Four new Keratinophyton species (Onygenaceae) from Europe
}

Roman Labuda ( $\sim$ roman.labuda@vetmeduni.ac.at)

Veterinarmedizinische Universitat Wien https://orcid.org/0000-0003-0761-178X

Andreas Bernreiter

BOKU: Universitat fur Bodenkultur Wien

Doris Hochenauer

BOKU: Universitat fur Bodenkultur Wien

Alena Kubátová

Charles University: Univerzita Karlova

Hazal Kandemir

Canisius Wilhelmina Hospital: Canisius Wilhelmina Ziekenhuis

Christoph Schüller

BOKU: Universitat fur Bodenkultur Wien

\section{Research}

Keywords: Chrysosporium, keratinophilic fungi, keratinolysis, one fungus = one name concept, new species, new combinations

Posted Date: May 7th, 2021

DOl: https://doi.org/10.21203/rs.3.rs-74808/v2

License: @ (i) This work is licensed under a Creative Commons Attribution 4.0 International License. Read Full License

Version of Record: A version of this preprint was published at IMA Fungus on July 8th, 2021. See the published version at https://doi.org/10.1186/s43008-021-00070-2. 


\section{Abstract}

Four new Keratinophyton species (Ascomycota, Pezizomycotina, Onygenales), K. gollerae, K. lemmensii, K. straussii and K. wagneri, isolated from soil samples originating from Europe (Austria, Italy and Slovakia) are described and illustrated. The new taxa are well supported by phylogenetic analysis of the internal transcribed spacer region (ITS) region, the combined data analysis of ITS and the nuclear large subunit (LSU) rDNA, and their phenotype. Based on ITS phylogeny, within the Keratinophyton clade, $K$. lemmensii is clustered with $K$. durum, K. hubeiense, K. submersum and $K$. siglerae, while K. gollerae, K. straussii and $K$. wagneri are resolved in a separate terminal cluster. All four new species can be well distinguished from other asexual morphs in the genus Keratinophyton based on phenotypical characteristics alone. Ten new combinations are proposed for Chrysosporium asexual morphs which are resolved in the monophyletic Keratinophyton clade.

\section{Introduction}

Keratinophyton is a genus of microscopic fungi (Ascomycota, Onygenales, Onygenaceae) comprising teleomorphic (sexual; producing ascomata with asci and ascospores) and anamorphic (asexual) species that live mostly on the remains of hair and feather in soil as saprotrophs (Cano and Guarro 1990; Crous et al. 2016; Sutton et al. 2013; Vidal et al. 2000). Formerly, they were classified in Aphanoascus Zukal mainly based on the presence of ascomata (cleistothecium) composed of a membranous peridium (Cano and Guarro 1990; Cano et al. 2002). In a review employing a phenotypic and phylogenetic approach, Cano et al. (2002) accepted 18 Aphanoascus species which are all sexual. Only recently, the polyphyletic status of Aphanoascus sensu lato has been resolved by Sutton et al. (2013) who established the genus Keratinophyton H.S. Randhawa \& R.S. Sandhu encompassing and redisposing six species, namely K. durum, K. hispanicum, K. multisporum, K. punsolae, K. saturnoideum and the type species $K$. terreum. Ascospores of Keratinophyton species are characterized by a conspicuous equatorial rim and pitted wall, while the genus Aphanoascus Zukal comprises species with reticulate ascospores without a rim (Sutton et al. 2013). Within Keratinophyton species, only K. multiporum is related with a Malbranchea anamorph (Cano et Guarro, 1990), while the remaining sexual species hitherto known have a Chrysosporium asexual morph. In addition to the above mentioned sexual species, the monophyletic Keratinophyton clade currently encompasses at least eleven species known only in their anamorphic state (Cano and Guarro 1990; Crous et al. 2016; Crous et al. 2017; Liang et al. 2009; Oorschot 1980; Vidal et al. 2000; Vidal et al. 2002; Zhang et al. 2016; Zhang et al. 2017). Recently, Crous et al. (2017) introduced a new asexual species, namely Keratinophyton turgidum Rahul Sharma \& Shouche, based on the morphology of its chrysosporium-like aleurioconidia and ITS locus phylogeny. The same authors stated that all species in this monophyletic clade which have a Chrysosporium asexual morph require redisposing in the genus Keratinophyton.

The presence of this large group of ubiquitous and keratinolytic species is rather common especially in areas with high animal activity that results in transfer of the keratinous material (fur, hairs, etc.) to the soil (Papini et al. 1998; Vidal et al. 2000). The following reports confirm their world-wide distribution and occurrence in different habitats usually associated with soil environments, e.g. soil in city parks (Papini et al. 1998; Vidyasagar et al. 2005), flower pots (Singh et al. 2009), sand in children's sandpits (Labuda et al. 2008), mud (Zaki et al. 2005), poultry farms (Anbu et al. 2004; Cano and Guarro 1990), marshy meadows, salt pans, desert, cultivated or uncultivated soils (Cano and Guarro 1990; Chmel and Vláčilíková 1977; Deshmukh 2004;

Deshmukh et al. 2008; Han et al. 2013; Javorekova et al. 2012; Zhang et al. 2016; Zhang et al. 2017) and river sediments (Ulfig et al. 1997; Vidal et al. 2000; Vidal et al. 2002). In general, these fungi are rarely reported as animal pathogens, and in fact, only two species $C$. echinulatum and C. pannicola (formerly known as C. evolceanui) have been involved in mycoses ( Hajsig et al. 1974; Cabanes et al. 2014; Crous et al. 2016).

During a microbiological survey of environmental samples (soil and compost) in July 2019, several interesting Chrysosporium asexual morphs were isolated. These isolates were phenotypically similar to those previously isolated from the same samples in August 2015 by one of the authors (RL). The isolates were designated as BiMM-F76, BiMM-F77 (also strain RL-07, isolated in July 2019), BiMM-F78 (also strains RL-05 and RL-06, isolated in July 2019) and BiMM-F250. All strains were further characterized in terms of morphology, physiology and molecular phylogeny. Phylogenetically informative sequences were obtained from internal transcribed spacer (ITS) region and the nuclear large subunit (LSU) rDNA. Overall, the resulting data revealed that these 
isolates represent novel asexual species of the genus Keratinophyton, and they are described and illustrated for the first time in this paper.

\section{Materials And Methods}

\section{Sample collection and isolation of the fungi}

A sample of a garden soil in Vieste (Italy) was collected in July, 2004. A sample of a forest soil in Tatranská Lomnica (The Slovak Republic) was collected in August 2011. A sample of compost from an agricultural base at the Institute of Agrobiotechnology (IFA Tulln, Austria) was collected in August 2015. All three samples were collected from the surface layer (in 3-5 cm deep). The samples were dried and stored in plastic bags in a fridge $\left(5-8{ }^{\circ} \mathrm{C}\right)$ until the time of analysis (August 2015 and July 2019). Isolation of the keratinophilic fungi was performed as described previously (Javorekova et al. 2012). Each sample was divided into 10 subsamples. The subsamples (20 g each) were poured into Petri dishes and soaked with antibiotic solution containing $0.5 \mathrm{~g}$ cycloheximide and $0.1 \mathrm{~g}$ chloramphenicol. Sterile defatted horse hair fragments (10 pieces of ca $2.0 \mathrm{~cm}$ per plate) were used as baits. The Petri dishes were then incubated at laboratory temperature $\left(23-25 \pm 1^{\circ} \mathrm{C}\right)$, under ambient daylight, for a period of 2-3 months and remoistened with sterile deionized water when necessary. The Petri dishes were checked weekly for the presence of fungi, and isolates were cultured on Sabouraud 4\% dextrose agar (SDA, Merck, Darmstadt, Germany) supplemented with $0.5 \mathrm{~g}$ cycloheximide and $0.05 \mathrm{~g}$ chloramphenicol. Pure cultures were then transferred onto potato dextrose agar (PDA, VWR, Leuven, Belgium). The preliminary identification of the resulting keratinophilic fungi (Chrysosporium asexual morphs) was carried out based on their phenotypic characteristics according to van Oorschot (1980) and Vidal et al. (2000; 2002).

\section{Morphological analysis}

For phenotypic determination, the strains were transferred (three-point inoculation with a needle) to PDA, malt extract agar (MEA, Merck, Darmstadt, Germany), and SDA, and incubated for 14 days in the dark at $25^{\circ} \mathrm{C}$. Christensen's urea agar (Sigma-Aldrich, St. Louis, USA) was used for additional physiological and biochemical characteristics ( $25^{\circ} \mathrm{C}, 14$ days, in the dark). Corn meal agar (CMA, Oxoid, Basingstoke, England), potato carrot agar (PCA) (Samson et al. 2010) and Emerson YpSs agar (Atlas, 1946) were used for stimulation of sexual reproduction $\left(20^{\circ} \mathrm{C}, 25^{\circ} \mathrm{C}\right.$, and $28^{\circ} \mathrm{C}$, up to 3 months, in the dark).

Colony size (in mm), colony structure and characteristics were noted after 14 days (on PDA, MEA, SDA, PYE, YpSs, CMA and PCA). However, the cultivation was prolonged up to 3 months in order to observe and record changes in pigmentation of the colonies as well as to determine the onset of sexual reproduction. In order to determine the optimal and minimum/maximum temperatures for growth, PDA, MEA and SDA plates were incubated at $5^{\circ} \mathrm{C}, 8^{\circ} \mathrm{C}, 10^{\circ} \mathrm{C}, 12^{\circ} \mathrm{C}, 15^{\circ} \mathrm{C}, 18{ }^{\circ} \mathrm{C}, 20^{\circ} \mathrm{C}, 25^{\circ} \mathrm{C}, 28-32{ }^{\circ} \mathrm{C}$, $35^{\circ} \mathrm{C}$ and $37^{\circ} \mathrm{C}$ and growth rate was measured at 14th day of cultivation. For comparative description of the macroscopic and microscopic characteristics, PDA was used according to Vidal et al. $(2002)$ and Crous et al. $(2016 ; 2017)$.

For determination of microscopic traits, PDA was used after 14-18 days. Conidiophore and conidia formation were observed in situ under low magnification (50-100x). Details of conidiophores, conidia (aleurioconidia) and other microscopic structures, such as width of hyphae, were observed in Melzer's reagent and lactic acid with cotton blue. The photomicrographs of the fungi were taken in Melzer's reagent and lactic acid with cotton blue using phase and Nomarski contrast on the Olympus BX51 microscope with Olympus DP72 camera and QuickPHOTO Micro 3.0 software. Photographs of the colonies were taken with a Sony DSCRX100.

Scanning electron microscopy (SEM) was performed on a JEOL JSM-6380 LV microscope (JEOL Ltd. Tokyo, Japan). Fungal samples were prepared according to a simplified method (Samson et al. 1979). Pieces of colonies (ca. $3 \times 5 \mathrm{~mm}$ ) growing on PDA were fixed in $6 \%$ glutaraldehyde overnight in the refrigerator (ca. $20 \mathrm{~h}$ ), then dehydrated in 2-methoxyethanol for $10 \mathrm{~min}$. This was followed by drying at a critical point and gold coating in BAL-TEC SCD 050 Sputter Coater. The samples were observed with spot size 35-39 and accelerating voltage 20-23 kV.

Dried herbarium specimens of the holotypes were deposited in the herbarium of the Mycological Department, National Museum in Prague, Czech Republic (PRM); the ex-type cultures were deposited in the Bioactive Microbial Metabolites (BiMM) Fungal Collection, UFT- Tulln (AT) and in the Culture Collection of Fungi (CCF), Prague (CZ). 


\section{Keratinolytic activity}

The keratinolytic activity was tested by placing a few sterilized blond hairs of a five years old child on the PDA plate $1 \mathrm{~cm}$ away from the point of inoculation (Oorschot 1980). Ability to digest keratin was observed after 21 days after incubation at $25^{\circ} \mathrm{C}$, in the dark. In addition, a hair perforation test according to de Hoog et al., (2020) using $25 \mathrm{~mL}$ water containing 2-3 drops 10\% yeast extract (YEW) was used as well. The hairs were examined microscopically after 14 and 21 days after inoculation at $25^{\circ} \mathrm{C}$ in the dark. By the end of the incubation a few pieces of hairs were taken out from the testing media (PDA and YEW). Overgrown fungus was deactivated with $70 \%$ ethanol and consequently discarded from the hair surface mechanically in the stream of a tap water. A degree of hair digestion-degradation (keratinolytic activity) was observed in a light microscope under 100x and 400x magnification. For the observation and microphotography of the hairs, water was used as mounting fluid. Intensity of degradation of the hair was estimated on a scale of 0 to 4 (Marchisio et al. 1994); 0, no degradation; 0-1, light degradation on the cuticle; 1 , moderate degradation on the cuticle and/or rare formation of boring hyphae; 2 , degradation of cuticle and cortex, with about $20 \%$ degradation of the hair; 3 , degradation of cuticle and cortex, with about $50 \%$ degradation of the hair; 4 , degradation of cuticle and cortex, with about $80 \%$ degradation of the hair. The photomicrographs of the hairs were taken using a Motic BA 310 microscope with Motic Image Plus 3.0 software. The final microscopic pictures were black-and-white inverted.

\section{DNA extraction, PCR amplification and sequencing}

DNA was extracted using a standard cetyltrimethyl ammonium bromide (CTAB) procedure, as described previously (Doyle and Doyle 1987). The internal transcribed spacer (ITS) region was amplified with primers ITS1-F (Gardes and Bruns 1993) and ITS4 (White et al. 1990) using Taq-polymerase. The D1/D2 domains of the large-subunit (28S) rRNA gene (LSU) were amplified and sequenced using the primer pair ITS1/TW14 (White et al. 1990; Mori et al. 2000). All reactions were performed in an Eppendorf Gradient MasterCycler (Eppendorf, Hamburg, Germany). Conditions for amplification of ITS and LSU domains: $95^{\circ} \mathrm{C}$ for 5 min; 35 cycles of $95{ }^{\circ} \mathrm{C}$ for $30 \mathrm{~s}, 54{ }^{\circ} \mathrm{C}$ for $30 \mathrm{~s}, 72{ }^{\circ} \mathrm{C}$ for $90 \mathrm{~s}$ and finally $5 \mathrm{~min}$ at $72{ }^{\circ} \mathrm{C}$. The PCR products were sequenced with the same primers used for the PCR amplifications (Microsynth AG, Balgach, Switzerland). All sequences obtained in this study were deposited in GenBank nucletide database (Table 1).

\section{Phylogenetic analysis}

For phylogenetic analysis, sequences were aligned with ClustalX (Larkin et al. 2007). Phylogenetic analysis based on ITS locus was performed using GTR+I+G4+F model with 1000 bootstrap replicates on IQ-TREE web server (Trifinopoulos et al. 2016) and ITS-LSU combined data phylogeny was constructed using MRBAYES v3.2.7adev (Ronquist and Huelsenbeck 2003) with default settings on the CIPRES portal (http://www.phylo.org/). Ctenomyces serratus (type species CBS 187.61) was used as an outgroup. TREEVIEW v1.6.6 (Page 1996) and iTOL v6 (Letunic and Bork 2019) were used to display and edit phylogenetic trees.

Table 1 List of strains included in the study. 


\begin{tabular}{|c|c|c|c|c|}
\hline \multirow[t]{2}{*}{ Species name } & \multirow[t]{2}{*}{ Strain $^{a}$} & \multirow[t]{2}{*}{ Source } & \multicolumn{2}{|c|}{ GenBank accession } \\
\hline & & & ITS & LSU \\
\hline A. canadensis & UAMH 4574 & Carnivore dung, Canada & AJ439435 & - \\
\hline A. clathratus & IMI 329400 & Arable soil, Spain & AJ439436 & - \\
\hline A. cubensis & FMR 4220 & Soil of tobacco field, Cuba & AJ439432 & - \\
\hline A. foetidus & CBS $453.75^{\top}$ & Myomys daltoni coat, Nigeria & KT155907 & KT155252 \\
\hline A. fulvescens & NBRC 30411 & Soil of rice paddy field, Japan & JN943432 & JN941547 \\
\hline A. keratinophilus & IFM $55159^{\top}$ & $\begin{array}{l}\text { Pasture land soil, Papua New } \\
\text { Guinea }\end{array}$ & NR165936 & NG064030 \\
\hline A. mephitalis & IMI $151084^{\top}$ & Dung of wolf, Canada & AJ439439 & AY176725 \\
\hline A. orissae & CBS 340.89 & Soil in animal husbandry, Kuwait & AJ390393 & - \\
\hline A. pinarensis & FMR 4221 & Forest soil, Cuba & AJ439433 & - \\
\hline A. reticulisporus & CBS $392.67^{\top}$ & Soil, New Zealand & MH859002 & MH870704 \\
\hline A. verrucosus & NBRC $32381^{\top}$ & Arable soil, Spain & NR131309 & NG057011 \\
\hline K. clavisporum (C. clavisporum) & $\mathrm{G} 80.1^{\top}$ & Plant root soil, China & KY026601 & - \\
\hline K. durum & CBS $118.85^{\top}$ & Soil, Nepal & MH861856 & AB075345 \\
\hline K. echinulatum (C. echinulatum) & CCF $4652^{\top}$ & Sole of the foot, Czechia & LT548276 & LT548276 \\
\hline K. fluviale (C. fluviale) & FMR $6005^{\top}$ & River sediments, Spain & AJ005367 & MT875000 \\
\hline K. gollerae & BiMM F250 ${ }^{\top}$ & Forest soil, Slovakia & MN633084 & MT874997 \\
\hline K. hispanicum & CBS $456.90^{\top}$ & Beach soil, Spain & KT155910 & MT875003 \\
\hline K. hubeiense (C. hubeiense) & EM66601 ${ }^{\top}$ & $\begin{array}{l}\text { Soil under the chicken feather, } \\
\text { China }\end{array}$ & KJ849227 & - \\
\hline K. Iemmensii & BiMM F76 $^{\top}$ & Compost soil, Austria & MN633082 & MT874998 \\
\hline K. linfenense (C. linfenense) & GZAC H31 ${ }^{\top}$ & Rhizosphere soil, China & NR158289 & - \\
\hline $\begin{array}{l}\text { K. minutisporosum (C. } \\
\text { minutisporosum) }\end{array}$ & IMI $379912^{\top}$ & River sediments, Spain & KT155616 & MT875001 \\
\hline K. pannicola (C. pannicola) & CBS $116.63^{\top}$ & Soil, India & AJ005368 & MH869834 \\
\hline K. punsolae & IMI $334818^{\top}$ & Arable soil, Spain & AJ439440 & - \\
\hline K. qinghaiense (C. qinghaiense) & $\begin{array}{l}\text { GZUIFR Chry } \\
11^{\top}\end{array}$ & Farmland soil, China & JX868607 & - \\
\hline K. saturnoideum & CBS $628.88^{\top}$ & Arable soil, Spain & NR077135 & AB075347 \\
\hline K. siglerae (C. siglerae) & UAMH $6541^{\top}$ & Garden soil, Spain & AJ131684 & MT875002 \\
\hline K. straussii & BiMM F78 $^{\top}$ & Garden soil, Italy & MN633081 & MT874996 \\
\hline K. submersum ( $C$ submersum) & CBS $101575^{\top}$ & River sediments, Spain & NR157445 & NG064180 \\
\hline K. terreum & CBS $342.64^{\top}$ & Lawn soil, India & KT155876 & KC989709 \\
\hline
\end{tabular}




\begin{tabular}{|lllll|}
\hline K. turgidum & ${\text { CBS } 142596^{\top}}^{\top}$ & Barber shop soil, India & KY290503 & KY962732 \\
\hline K. wagneri & BiMM F77 $^{\top}$ & Forest soil, Slovakia & MN633083 & MT874999 \\
\hline Ct. serratus & CBS $187.61^{\top}$ & Soil, Australia & NR144890 & AY176733 \\
\hline
\end{tabular}

a BiMM, Bioactive Microbial Metabolites Unit, UFT-Tulln, Austria; UAMH, University of Alberta Microfungus Collection and Herbarium; IMI, The International Mycological Institute in Kew, England; FMR, Facultat de Medicina in Ciències de la Salut, Reus, Spain; CBS, Centraalbureau voor Schimmelcultures (located in Westerdijk Fungal Biodiversity Institute), Utrecht, the Netherlands; NBRC, NITE Biological Resource Center, Japan; IFO, Institute for Fermentation, Osaka, Japan; G, EM, and GZUIFR strains, The Institute of Fungus Resource, Guizhou University, China; A, Aphanoascus; K, Keratinophyton; C, Chrysosporium; Ct, Ctenomyces; ${ }^{\top}$, type strain. Data in bold was produced in the present study.

\section{Results}

\section{Morphological analyses and keratin degradation}

The results of the morphological analyses were given for each novel species under the taxonomy section. Temperature dependent growth of the new Keratinophyton species on PDA, MEA and SDA after 14 days were provided in Table S1a-c. Briefly, $K$. lemmensii growth better than the other three new Keratinophyton species with inoculations on the same media and at the same incubation temperatures. All species showed good growth at $20^{\circ} \mathrm{C}-25^{\circ} \mathrm{C}$ on all three types of media.

Ability to digest keratin after 21 days was observed in all four novel species on both testing media (PDA and YEW). However, a value of attack intensity on the hair according to scale of Marchisio et al. (1994) substantially differed among the species; being very strong in $K$. gollerae and $K$. straussii $(=4)$, moderate in $K$. wagneri $(=2)$ and weak in $K$. lemmensii with a value of 0-1 (Fig. 10).

\section{Phylogenetical analysis}

The phylogenetic tree of ITS dataset ( $n=32$ ) was 551 bp length which had 286 variable and 200 parsimony-informative sites. ITS phylogeny indicated the presence of six terminal clusters in the monophyletic Keratinophyton clade with high bootstrap support and low interspecific sequence divergence (Fig. 1a). Keratinophyton saturnoideum and K. minutisporosum formed basal branched to the clade. The isolate BiMM-F76 (named as K. lemmensii sp. nov.) was found close to K. durum (with $99 \%$ ITS and 95\% LSU similarity) clustered also with $K$. hubeiense and $K$. submersum. In addition, $K$. straussii sp. nov., $K$. gollerae sp. nov., and K. wagneri sp. nov., represented by the ex-type cultures BiMM-F78, BiMM-F250 and BiMM-F77, respectively, were resolved in a separate terminal cluster-lineage. A concatenated phylogeny of ITS and LSU sequences ( $n=22)$ was 1094 bp length and included 354 variable and 224 parsimony-informative sites. According to combined data analysis, four clusters were found in the Keratinophyton clade and $K$. saturnoideum formed a basal branch (Fig. 1b). Differently from the ITS phylogeny, K. durum was found in a different cluster than K. submersum and K. lemmensii in the concatenated loci phylogeny (Fig. 1b).

\section{Taxonomy}

Keratinophyton lemmensii Labuda, Bernreiter, Kubátová \& Schüller sp. nov. MycoBank. MB833632. (Figs 2 and 3).

Etymology: Named in honour of Professor Marc Lemmens, Laboratory of Plant Protection (IFA, BOKU, AT), an expert in the fungal plant pathology.

Diagnosis: Presence of filiform often sinusoidal conidia and abundant arthroconidia, production of bright yellow pigment on PDA and good growth at $30^{\circ} \mathrm{C}$. Sequence data from ITS separate this taxon from all other Keratinophyton species.

Type: Austria: Tulln and der Donau, from compost soil at IFA Tulln, Aug. 2015, R. Labuda (PRM 952498-holotype; BiMM-F76 = CCF 6359 - ex-type cultures). ITS sequence, GeneBank MN633082; LSU sequence, GeneBank MT874998. 
Description: Sexual morph not observed on any of the media used in the present study. Asexual morph on PDA. Vegetative mycelium consisting of hyaline, smooth-walled, septate, sparsely branched hyphae, 1.5-5.0 $\mu \mathrm{m}$ diam. Racquet hyphae observed. Conidia (aleurioconidia), hyaline, white in mass, thin-walled, smooth to sparsely irregularly ornamented with minute warts. Terminal and lateral conidia born on main fertile hyphae as sessile or on short protrusions, solitary, 1-3 (5) per conidiogenous cell, obovate to clavate, 1-celled, (3.0-)4.5-6.5(-7.5) x (1.5-)2.0-2.5(-4.0) $\mu \mathrm{m}$ (mean = 4.9 $\pm 0.8 \times 2.4 \pm 0.4 \mu \mathrm{m}, \mathrm{n}=120)$, and filiform, often sinusoidal, 1- to 2-celled, 25-35(-40) $\mu \mathrm{m}$ long conidia also present. Intercalary conidia (arthroconidia) present, 10-15 $\mu \mathrm{m}$ long. Chlamydospores not observed.

Culture characteristics: Colonies on PDA 28-35 mm diam at $25^{\circ} \mathrm{C}$, after 14 days, floccose, with good sporulation, white, flat, slightly elevated (umbonate) at the center, with irregular margin, reverse lemon yellow, soluble pigment bright yellow, a few small clear to yellow-orange exudate droplets produced. At $30^{\circ} \mathrm{C}, 38-45 \mathrm{~mm}$ diam after 14 days, white, flat, floccose and radially sulcate with good sporulation only at the center, and with lemon yellow reverse. Colonies on SDA $28-35 \mathrm{~mm}$ diam at $25^{\circ} \mathrm{C}$, after 14 days, morphology similar to PDA, without exudate and with pale yellow reverse. At $30^{\circ} \mathrm{C}, 30-32 \mathrm{~mm}$ diam after 14 days, white, flat, floccose with good sporulation, with pale yellow reverse. Colonies on MEA $20-25 \mathrm{~mm}$ diam at $25^{\circ} \mathrm{C}$ after 14 days, morphology similar to PDA, exudate absent, and pale-yellow reverse. At $30^{\circ} \mathrm{C}, 18-20 \mathrm{~mm}$ diam after 14 days, white, floccose and radially sulcate, with good sporulation, and with pale yellow reverse. Colonies on CMA and PCA, $45-50 \mathrm{~mm}$ diam at $25^{\circ} \mathrm{C}$, after 21 days, white, flat and spread with poor sporulation, reverse white. No ascomata observed after prolonged incubation (3 months). The optimum temperature for growth on PDA, SDA and MEA was between $25-30{ }^{\circ} \mathrm{C}$ (Table S2a-c). Minimum growth (1-2 mm diam) was observed at $8{ }^{\circ} \mathrm{C}$. The maximum temperature for growth was $32^{\circ} \mathrm{C}$ (microcolonies to $1 \mathrm{~mm}$ diam). Keratinolytic activity very weak (Fig. 10a), with hair attack intensity = 0-1. Urease activity positive (after 3 days of incubation).

Notes: Based on a search of NCBI GenBank nucleotide database, the closest hit for $K$. lemmensii using the ITS sequence is $K$. durum (FMR5651; Genbank acc. AJ439434; identities = 568/577 (98\%), gaps 0/577 (0\%). Phenotypically, K. lemmensii is unique and differs from the relatives in the same clade ( $K$. durum, $K$. hubeiense, $K$. submersum, and $K$. siglerae) by the combination of the following features: (1) presence of long filiform often sinusoidal uni- to bicellular conidia (up to $40 \mu \mathrm{m}$ ), (2) white, moderately fast growing colonies $\left(28-35 \mathrm{~mm}\right.$ diam, on PDA at $\left.25^{\circ} \mathrm{C}\right)$, (3) production of lemon yellow pigment on PDA at $25^{\circ} \mathrm{C},(4)$ minimum $\left(8{ }^{\circ} \mathrm{C}\right)$ and maximum $\left(32^{\circ} \mathrm{C}\right)$ growth temperature, (5) very weak keratin digestion after $21 \mathrm{~d}$. Along with foregoing features, $K$. lemmensii can be directly distinguished from the phylogenetically closest $K$. durum asexual morph also by the presence of numerous arthroconidia which are completely missing in the latter species (Cano and Guarro 1990; Currah 1985).

Keratinophyton gollerae Labuda, Bernreiter, Kubátová, Schüller \& Strauss sp. nov.

MycoBank. MB 833633. (Figs. 4 and 5).

Etymology: Named in honour of Dr. Sabine Strauss-Goller, the Department of Applied Genetics and Cell Biology, Fungal Genetics and Genomics Laboratory (BOKU, AT), an expert in the fungal genetics and indoor mold analytics.

Diagnosis: Production of slender and mostly smooth-walled conidia, no growth at $30^{\circ} \mathrm{C}$, and strong keratinolytic ability. Sequence data from ITS separate this taxon from all others Keratinophyton species.

Type: The Slovak Republic: Tatranská Lomnica, from forest soil, Jul. 2019, R. Labuda (PRM 952499 - holotype; BiMM-F250 = CCF 6360 - ex-type cultures). ITS sequence, GeneBank MN633084; LSU sequence, GeneBank MT874997.

Description: Sexual morph not observed on any of the media used. Asexual morph on PDA. Vegetative mycelium consisting of hyaline, septate, smooth-walled, sparsely to pronouncedly branched hyphae, often in right angles, 1.0-5.0 $\mu \mathrm{m}$ diam. Racquet hyphae observed. Conidia (aleurioconidia), hyaline, white in mass, thin-walled, mostly smooth to finely roughened, some also verrucose (under light microscope) and irregularly ornamented with minute warts (visible under SEM). Terminal and lateral conidia born on main fertile hyphae or from side branches of variable length, sessile or on short protrusions, occasionally only very slightly swollen and of variable length, solitary, 1-3 (5) per conidiogenous cell, obovate to clavate, mostly 1-celled, $(3.5-) 5.0-7.0(-10.0) \times(1.5-) 2.0-2.5(-3.0) \mu \mathrm{m}$ (mean= 5.2 $\pm 0.9 \times 2.2 \pm 0.2 \mu \mathrm{m}, \mathrm{n}=120)$. Intercalary conidia not observed. Chlamydospores not observed. 
Culture characteristics: Colonies on PDA 20-22 mm diam at $25^{\circ} \mathrm{C}$, after 14 days, powdery to downy (mealy), with abundant sporulation, white to creamy, flat, umbonate at the center, with regular colony margin submersed into agar, reverse white to slightly yellowish, no pigment or exudate produced. At $30^{\circ} \mathrm{C}$, no growth (germination only). Colonies on SDA $23-25 \mathrm{~mm}$ diam at $25^{\circ} \mathrm{C}$, after 14 days, morphology similar to PDA with more floccose colony margin and more yellowish colonies, with dark yellow reverse. At $30^{\circ} \mathrm{C}$, no growth (no germination). Colonies on MEA $14-16 \mathrm{~mm}$ diam at $25^{\circ} \mathrm{C}$, after 14 days, morphology similar to PDA with more floccose colonies and with yellow reverse. At $30^{\circ} \mathrm{C}$, no growth (no germination). Colonies on CMA and PCA attaining 15-20 mm diam at $25^{\circ} \mathrm{C}$, after 21 days, white, granular, with good sporulation, reverse yellowish. No ascomata observed after prolonged incubation (3 months). The optimum temperature for growth on PDA, SDA and MEA was between 15 and $25^{\circ} \mathrm{C}$ (Table S2a-c). Minimum growth (microcolonies to $1 \mathrm{~mm}$ in diam.) was observed at $10^{\circ} \mathrm{C}$. Germination of the spores was observed at $8^{\circ} \mathrm{C}$. The maximum temperature for growth on PDA was $29^{\circ} \mathrm{C}$, while $27^{\circ} \mathrm{C}$ and $28^{\circ} \mathrm{C}$ on MEA and SDA, respectively (microcolonies to $1 \mathrm{~mm}$ diam). Keratinolytic activity very strong (Fig 10b), with hair attack intensity $=4$. Urease activity negative (after 14 days of incubation).

Notes: Based on a search of NCBI GenBank nucleotide database, the closest hit for $K$. gollerae using the ITS sequence is $K$. minutisporosum (as Chrysosporium minutisporosum CBS 101577; GeneBank acc. KT155616), with identity $=487 / 543(90 \%)$ and gaps $11 / 543$ (2\%). Phenotypically, K. gollerae can be readily distinguished from the two other species $K$. straussii and $K$. wagneri, in the same clade by its inability to grow at $30^{\circ} \mathrm{C}$, narrower and mostly smooth to finely roughened conidia, and its slower growth at $25^{\circ} \mathrm{C}$ on PDA. Moreover, in comparison with $\mathrm{K}$. straussii, $K$. gollerae grows substantially faster at $15{ }^{\circ} \mathrm{C}$ (on PDA and SDA) and its spores germinate at $8{ }^{\circ} \mathrm{C}$ (see Table $\left.\mathrm{S} 1 \mathrm{a}-\mathrm{c}\right)$.

Keratinophyton straussii Labuda, Bernreiter, Kubátová \& Schüller sp. nov.

MycoBank. MB 833634. (Figs. 6 and 7).

Etymology. Named in honour of Professor Joseph Strauss, a head of the Department of Applied Genetics and Cell Biology, founder of the Fungal Genetics and Genomics Laboratory (BOKU, AT), an expert in the fungal genetics, epigenetics and functional genomics.

Diagnosis: Coarsely roughened conidia produced from swollen conidiogenous cells, optimal growth at $30^{\circ} \mathrm{C}$, with strong keratinolytic ability. Sequence data from ITS separate this taxon from other Keratinophyton species.

Type: Italy: Vieste, from garden soil, Aug. 2015, R. Labuda (PRM 952500 - holotype; BiMM-F78 = CCF 6361 - ex-type cultures). ITS sequence, GeneBank MN633081; LSU sequences, GeneBank MT874996.

Description: Sexual morph not observed on any of the media used. Asexual morph on PDA. Vegetative mycelium consisting of hyaline, septate, smooth-walled, sparsely to pronouncedly branched hyphae, usually in right angles, 1.5-4.0 $\mu \mathrm{m}$ diam. Racquet hyphae observed. Conidia (aleurioconidia), hyaline, white to yellowish in mass, thin-walled and regularly ornamented with minute warts (visible under SEM) and coarsely roughened (under light microscope). Terminal and lateral conidia born on main fertile hyphae or from side branches of variable length, sessile or on short protrusions, commonly slightly swollen and of variable length, solitary, 1-3 (5) per conidiogenous cell, obovate to clavate, 1-celled, (3.5-)4.5-5.0(-6.5) x (2.0-)2.5-3.0(-3.5) $\mu \mathrm{m}$ (mean $=4.9 \pm 0.4 \times 2.6 \pm 0.2 \mu \mathrm{m}, \mathrm{n}=120)$, very rarely 2 - to 3 -celled, up to $12 \mu \mathrm{m}$ large aleurioconida also present. Intercalary conidia not observed. Chlamydospores not observed.

Culture characteristics: Colonies on PDA 24-28 mm diam at $25^{\circ} \mathrm{C}$, after 14 days, powdery to downy (mealy), with abundant sporulation, white to very slightly creamy yellowish, flat, slightly elevated (umbonate) remaining powdery at the center, with irregular margin, reverse white with slightly yellowish center, no pigment or exudate produced. At $30^{\circ} \mathrm{C}, 15-20 \mathrm{~mm}$ diam after 14 days, white to creamy yellowish, flat, powdery to downy (mealy) with very good sporulation, and with white to yellowish reverse. Colonies on SDA attaining $16-20 \mathrm{~mm}$ diam at $25^{\circ} \mathrm{C}$, after 14 days, morphology similar to PDA with dark yellow reverse. In age (after 5 weeks) yellow pigment is produced and colony reverse becomes bright reddish-yellow to orange. At $30^{\circ} \mathrm{C}, 15-20 \mathrm{~mm}$ diam after 14 days, white to creamy yellowish, umbonate, with strong sporulation, and with yellowish reverse. Colonies on MEA 18-20 mm diam at $25^{\circ} \mathrm{C}$, after 14 days, morphology similar to PDA with more floccose and yellowish. At $30^{\circ} \mathrm{C}, 5-10 \mathrm{~mm}$ diam after 14 days, slightly umbonate, floccose to granular, with very good sporulation white to yellowish, and with yellow reverse. 
Colonies on CMA and PCA $18-20 \mathrm{~mm}$ diam at $25^{\circ} \mathrm{C}$, after 21 days, white, granular, good sporulation, reverse yellowish. No ascomata observed after prolonged incubation (3 months). The optimum temperature for growth on PDA, SDA and MEA was between 20 and $25^{\circ} \mathrm{C}$ (Table S1a-c). Minimum growth (microcolonies to 1-2 mm diam) was observed at $10{ }^{\circ} \mathrm{C}$. No germination of the spores was observed at $8{ }^{\circ} \mathrm{C}$. The maximum temperature for growth was $32{ }^{\circ} \mathrm{C}$ (microcolonies to $1-2 \mathrm{~mm}$ diam). Keratinolytic activity very strong (Fig 10c), with hair degradation intensity $=4$. Urease activity negative (after 14 days of incubation).

Notes: Based on a search of NCBI GenBank nucleotide database, the closest hit for $K$. straussii using the ITS sequence is $K$. minutisporosum (as Chrysosporium minutisporosum CBS 101577; GeneBank acc. KT155616), with identity $=489 / 543(90 \%)$ and gaps 10/543 (1\%). Phenotypic similarities see under K. wagneri.

Additional material examined: Italy: Vieste, from garden soil, isolated from different sub-samples, July 2019, R. Labuda, strain RL05 (ITS sequence, MT898644; LSU sequence, MT898648) and strain RL-06 (ITS sequence, MT898645; LSU sequence, MT898649) referring to personal collection of RL. At $30^{\circ} \mathrm{C}$ they grew relatively better (up to $5 \mathrm{~mm}$ larger in diam) than the ex-type culture.

Keratinophyton wagneri Labuda, Bernreiter, Kubátová \& Schüller sp. nov.

MycoBank. MB 833635. (Figs. 8 and 9).

Etymology: Named in honour of Professor Martin Wagner, Head of Unit for Food Microbiology and Head of Institute for Food Safety, Food Technology and Veterinary Public Health, University of Veterinary Medicine, Vienna (Austria), an expert in the veterinary microbiology.

Diagnosis: Robust and coarsely roughed conidia produced from non-swollen conidiogenous cells, none to very limited growth at $30{ }^{\circ} \mathrm{C}$, and production of pink pigment on PCA after prolonged incubation (3 weeks). Sequence data from ITS separate this taxon from all others Keratinophyton species.

Type: The Slovak Republic: Tatranská Lomnica, from forest soil, Aug. 2015, R. Labuda (PRM 952501 - holotype; BiMM-F77 = CCF 6362 - ex-type cultures). ITS sequence, GeneBank MN633083; LSU sequence, GeneBank MT874999.

Description: Sexual morph not observed on any of the media used. Asexual morph on PDA. Vegetative mycelium consisting of hyaline, septate, smooth-walled, sparsely to pronouncedly branched hyphae, 2.0-6.0 $\mu \mathrm{m}$ diam. Racquet hyphae present. Conidia (aleurioconidia), hyaline, white to yellowish in mass, thin-walled and regularly ornamented with minute warts with minute warts (visible under SEM) and coarsely roughened (under light microscope). Terminal and lateral conidia born on main fertile hyphae or from side branches of variable length, sessile or on short protrusions, occasionally swollen and of variable length, solitary, 1-4 (10) per conidiogenous cell, obovate to clavate, single celled, (4.0-) 5.5-6.5 (-8.0) x (2.5-) 3.0-3.5(-4.0) $\mu \mathrm{m}(\mathrm{mean}=5.7 \pm 0.4 \mathrm{x}$ $3.2 \pm 0.2 \mu \mathrm{m}, \mathrm{n}=120)$, rarely 2 -celled, up to $12 \mu \mathrm{m}$ large ones also present. Intercalary conidia not observed. Chlamydospores not observed.

Culture characteristics: Colonies on PDA 25-30 mm diam at $25^{\circ} \mathrm{C}$, after 14 days, powdery to downy (mealy), with abundant sporulation, white to slightly yellowish, flat, slightly elevated (umbonate) and more floccose at the center, with irregular margin, reverse white with slightly yellowish center, no pigment or exudate produced. At $30^{\circ} \mathrm{C}, 4-8 \mathrm{~mm}$ diam after 14 days, white, floccose with poor sporulation, and with yellowish reverse. Colonies on SDA $14-18 \mathrm{~mm}$ diam at $25^{\circ} \mathrm{C}$, after 14 days, morphology similar to PDA. In age, yellowish-brown (amber) pigment is produced and colony reverse becomes dark reddish-brown (after 4 weeks). At $30{ }^{\circ} \mathrm{C}$, no growth or only microcolonies were observed. Colonies on MEA 18-22 mm diam at $25^{\circ} \mathrm{C}$, after 14 days, morphology similar to PDA with more yellowish colonies. At $30^{\circ} \mathrm{C}$, no growth or only micro-colonies were observed. Colonies on CMA and PCA $20-25 \mathrm{~mm}$ diam at $25^{\circ} \mathrm{C}$, after 21 days, white to yellowish, granular, good sporulation, reverse yellowish. Pinkish pigment production observed after 3-4 weeks on PCA (in both tested strains). No ascomata observed after prolonged incubation (3 months). The optimum temperature for growth on PDA, SDA and MEA was between 20 and $25^{\circ} \mathrm{C}$ (Table S2a-c). Minimum growth (1-2 mm diam) was observed at $10{ }^{\circ} \mathrm{C}$, and germination of majority of the spores was observed at $8{ }^{\circ} \mathrm{C}$. The maximum 
temperature for growth was $31^{\circ} \mathrm{C}(1-3 \mathrm{~mm}$ diam). Keratinolytic activity weak to moderate (Fig $10 \mathrm{~d})$, with hair attack intensity = 2. Urease activity negative (after 14 days of incubation).

Notes: Based on a search of NCBI GenBank nucleotide database, the closest hit for $K$. wagneri using the ITS sequence is $K$. minutisporosum (as Chrysosporium minutisporosum CBS 101577; Genebank: KT155616); with identity $=486 / 541$ (90\%) and gaps $11 / 541$ (2\%). Morphologically, K. straussii and $K$. wagneri seem to be very similar, however, they can be distinguished based on (1) size of conidia (av. $=4.9 \times 2.5 \mu \mathrm{m}$ vs $5.7 \times 3.2 \mu \mathrm{m}$ ), (2) growth at $30^{\circ} \mathrm{C}$ on PDA (15-20 mm vs $3-4 \mathrm{~mm}$ diam), (3) morphology of conidiogenous cells (commonly vs non- to occasionally swollen), (4) colony pigmentation on SDA after prolonged incubation (bright orange vs dark brown), and (5) keratinolytic ability after 3 weeks (very strong vs moderate). In addition, the production of a pinkish pigment on PCA after 3-4 weeks (at $20^{\circ} \mathrm{C}$ and $25^{\circ} \mathrm{C}$ ) has been observed only in $\mathrm{K}$. wagneri. Moreover, conidia of this species are more coarsely roughed (warty) than those in K. straussii (Fig. $8 \mathrm{c}-\mathrm{e}$ ).

Additional material examined: The Slovak Republic: Tatranská Lomnica, from forest soil, isolated from a different sub-sample, July 2019, R. Labuda, RL-07 (ITS sequence, MT903275; LSU sequence, MT903309) referring to personal collection of RL, phenotypically identical with the ex-type culture.

The main distinguishing phenotypic characteristics of the four new species compared with the other asexual members of the genus Keratinophyton are outlined in the Table 2.

Table 2 Comparison of the key phenotypic characteristics of Keratinophyton spp. 


\begin{tabular}{|c|c|c|c|c|c|c|c|}
\hline Species & $\begin{array}{l}\text { Growth at } \\
30^{\circ} \mathrm{C} \text { on } \\
\mathrm{PDA}^{*}\end{array}$ & $\begin{array}{l}\text { Colony Color } \\
\text { Growth/ Reverse } \\
\text { on PDA at } 25^{\circ} \mathrm{C} \text {, } \\
\text { after } 14 \mathrm{~d}^{\star \star}\end{array}$ & $\begin{array}{l}\text { Conidial } \\
\text { Shape }\end{array}$ & $\begin{array}{l}\text { Conidial } \\
\text { dimensions } \\
(\mu \mathrm{m})\end{array}$ & $\begin{array}{l}\text { Conidial } \\
\text { Surface }\end{array}$ & $\begin{array}{l}\text { Intercalary } \\
\text { conidia }\end{array}$ & References \\
\hline $\begin{array}{l}\text { K. gollerae sp. } \\
\text { nov. }\end{array}$ & None & $\begin{array}{l}\text { White to creamy, } \\
20-22 \mathrm{~mm} / \text { white } \\
\text { to yellowish }\end{array}$ & $\begin{array}{l}\text { Obovoid to } \\
\text { clavate }\end{array}$ & $\begin{array}{l}5.0-7.0 x \\
2.0-2.5\end{array}$ & $\begin{array}{l}\text { Smooth to } \\
\text { finely } \\
\text { roughened }\end{array}$ & Absent & This study \\
\hline $\begin{array}{l}\text { K. lemmensii sp. } \\
\text { nov. }\end{array}$ & $\begin{array}{l}\text { Present } \\
\text { (good) }\end{array}$ & $\begin{array}{l}\text { White, 28-35 } \\
\text { mm/lemon } \\
\text { yellow }\end{array}$ & $\begin{array}{l}\text { Clavate to } \\
\text { filiform }\end{array}$ & $\begin{array}{l}3.0-40 \mu \mathrm{m} \\
(1-\text { to } 2- \\
\text { celled })\end{array}$ & Smooth & Present & This study \\
\hline \multirow{2}{*}{$\begin{array}{l}\text { K. straussii sp. } \\
\text { nov. }\end{array}$} & \multirow{2}{*}{$\begin{array}{l}\text { Present } \\
\text { (good) }\end{array}$} & White to creamy, & \multirow{2}{*}{$\begin{array}{l}\text { Obovoid to } \\
\text { clavate }\end{array}$} & \multirow{2}{*}{$\begin{array}{l}4.5-5.0 x \\
2.5-3.0\end{array}$} & \multirow[t]{2}{*}{ Verrucose } & \multirow[t]{2}{*}{ Absent } & \multirow[t]{2}{*}{ This study } \\
\hline & & $\begin{array}{l}24-28 \mathrm{~mm} / \text { white } \\
\text { to yellowish }\end{array}$ & & & & & \\
\hline \multirow[t]{2}{*}{$\begin{array}{l}\text { K. wagneri sp. } \\
\text { nov. }\end{array}$} & \multirow[t]{2}{*}{$\begin{array}{l}\text { Present } \\
\text { (inhibited) }\end{array}$} & $\begin{array}{l}\text { White to } \\
\text { yellowish, }\end{array}$ & \multirow[t]{2}{*}{$\begin{array}{l}\text { Obovoid to } \\
\text { clavate }\end{array}$} & \multirow[t]{2}{*}{$\begin{array}{l}4.0-8.0 x \\
2.5-4.0\end{array}$} & \multirow[t]{2}{*}{ Verrucose } & \multirow[t]{2}{*}{ Absent } & \multirow[t]{2}{*}{ This study } \\
\hline & & $\begin{array}{l}25-30 \mathrm{~mm} / \text { white } \\
\text { to yellowish }\end{array}$ & & & & & \\
\hline K. clavisporum & $\begin{array}{l}\text { Present } \\
\text { (inhibited) } \rrbracket\end{array}$ & $\begin{array}{l}\text { White, } 53 \mathrm{~mm} \text { (26 } \\
\left.{ }^{\circ} \mathrm{C}\right) / \text { red-brown }\end{array}$ & $\begin{array}{l}\text { Clavate to } \\
\text { long - } \\
\text { ellipsoidal }\end{array}$ & $\begin{array}{l}5.0-10 x \\
2.5-5.0\end{array}$ & Smooth & Absent & $\begin{array}{l}\text { Zhang et } \\
\text { al. } 2017\end{array}$ \\
\hline K. echinulatum & $\begin{array}{l}\text { Present } \\
\text { (good) }\end{array}$ & $\begin{array}{l}\text { Yellow to pale } \\
\text { orange yellow, } \\
28-45 \\
\text { mm/orange } \\
\text { yellow }\end{array}$ & $\begin{array}{l}\text { Obovoid to } \\
\text { clavate }\end{array}$ & $\begin{array}{l}4.5-7.0 x \\
2.5-4.0\end{array}$ & Echinulate & Present & $\begin{array}{l}\text { Crous et } \\
\text { al. } 2016\end{array}$ \\
\hline K. fluviale & $\begin{array}{l}\text { Present } \\
\text { (good) }\end{array}$ & $\begin{array}{l}\text { White to } \\
\text { yellowish white, } \\
60-70 \mathrm{~mm}(30 \\
\left.{ }^{\circ} \mathrm{C}\right) / \text { brownish } \\
\text { orange }\end{array}$ & $\begin{array}{l}\text { Obovate, } \\
\text { clavate, } \\
\text { nearly } \\
\text { ellipsoidal } \\
\text { or pyriform }\end{array}$ & $\begin{array}{l}3.5-15 x \\
2.0-3.0(1- \\
\text { and 2- } \\
\text { celled })\end{array}$ & Verrucose & $\begin{array}{l}\text { Present } \\
\text { (very rare) }\end{array}$ & $\begin{array}{l}\text { Vidal et al. } \\
2000\end{array}$ \\
\hline K. qinghaiense & $\begin{array}{l}\text { Present } \\
\text { (good) } \square\end{array}$ & $\begin{array}{l}\text { White to } \\
\text { yellowish, } 30 \mathrm{~mm} \\
\text { (7days)/yellowish }\end{array}$ & $\begin{array}{l}\text { Clavate to } \\
\text { cylindrical }\end{array}$ & $\begin{array}{l}3.6-13 \\
\times 1.8-3.6\end{array}$ & Smooth & Present & $\begin{array}{l}\text { Han et. al. } \\
2013\end{array}$ \\
\hline K. hubeiense & $\begin{array}{l}\text { Present } \\
\text { (inhibited) } \rrbracket\end{array}$ & $\begin{array}{l}\text { Grey white to } \\
\text { white, 65-67 } \\
\mathrm{mm} / \text { reverse } \\
\text { yellowish }\end{array}$ & $\begin{array}{l}\text { Obovoid to } \\
\text { ellipsoidal }\end{array}$ & $\begin{array}{l}2.2-4.3 x \\
1.6-3.2\end{array}$ & Smooth & Absent & $\begin{array}{l}\text { Zhang et } \\
\text { al. } 2016\end{array}$ \\
\hline K. linfenense & $\begin{array}{l}\text { Present } \\
\text { (good) }\end{array}$ & $\begin{array}{l}\text { White to cream, } \\
72 \mathrm{~mm}(30 \\
\left.{ }^{\circ} \mathrm{C}\right) / \text { white to light } \\
\text { yellow }\end{array}$ & $\begin{array}{l}\text { Ellipsoidal } \\
\text { to fusiform, } \\
\text { also clavate }\end{array}$ & $\begin{array}{l}3.2-5.4 x- \\
1.4-2.2\end{array}$ & Smooth & Absent & $\begin{array}{l}\text { Liang et al. } \\
2009\end{array}$ \\
\hline $\begin{array}{l}\text { K. } \\
\text { minutisporosum }\end{array}$ & $\begin{array}{l}\text { Present } \\
\text { (inhibited) }\end{array}$ & $\begin{array}{l}\text { White to } \\
\text { yellowish white, } \\
55-70 \mathrm{~mm} / \text { white }\end{array}$ & $\begin{array}{l}\text { Pyriform or } \\
\text { subglobose, } \\
\text { also clavate }\end{array}$ & $\begin{array}{l}3.0-4.0(- \\
11) \times 1.5- \\
3.5\end{array}$ & Verrucose & $\begin{array}{l}\text { Present } \\
\text { (very rare) }\end{array}$ & $\begin{array}{l}\text { Vidal et al. } \\
2002\end{array}$ \\
\hline K. pannicola & $\begin{array}{l}\text { Present } \\
\text { (good) }\end{array}$ & $\begin{array}{l}\text { White to pale } \\
\text { yellow, }\end{array}$ & $\begin{array}{l}\text { Obovoid to } \\
\text { clavate }\end{array}$ & $\begin{array}{l}6.0-11 x \\
3.5-4.5\end{array}$ & Verrucose & Present & $\begin{array}{l}\text { Oorschot } \\
1980\end{array}$ \\
\hline & & $\begin{array}{l}20-38 \mathrm{~mm} \\
\left(\mathrm{PYE}^{\star \star \star}\right) / \text { pale } \\
\text { brown }\end{array}$ & & & & abundant) & \\
\hline K. siglerae & $\begin{array}{l}\text { Present } \\
\text { (good) }\end{array}$ & $\begin{array}{l}\text { Griseous orange, } \\
15-20 \mathrm{~mm}(21 \\
\text { days } / \text { pale } \\
\text { brown }\end{array}$ & $\begin{array}{l}\text { Cylindrical } \\
\text { to clavate }\end{array}$ & $\begin{array}{l}5.0-30 x \\
2.0-3.5 \\
1 \text {-and 2- } \\
\text { celled }\end{array}$ & $\begin{array}{l}\text { Smooth to } \\
\text { slightly } \\
\text { verrucose }\end{array}$ & Present & $\begin{array}{l}\text { Cano and } \\
\text { Guarro } \\
1994\end{array}$ \\
\hline
\end{tabular}




\begin{tabular}{|c|c|c|c|c|c|c|c|}
\hline K. submersum & $\begin{array}{l}\text { Present } \\
\text { (inhibited) }\end{array}$ & $\begin{array}{l}\text { Yellowish white, } \\
50- \\
60 \mathrm{~mm} / \text { yellowish } \\
\text { white }\end{array}$ & $\begin{array}{l}\text { Clavate, } \\
\text { also } \\
\text { pyriform, } \\
\text { obovoid } \\
\text { and } \\
\text { subglobose }\end{array}$ & $\begin{array}{l}4.0-35 x \\
2.5-5.0 \\
\text { (1- to } 4- \\
\text { celled) }\end{array}$ & $\begin{array}{l}\text { Smooth to } \\
\text { verrucose- } \\
\text { thick- } \\
\text { walled }\end{array}$ & $\begin{array}{l}\text { Present } \\
\text { (in old } \\
\text { cultures) }\end{array}$ & $\begin{array}{l}\text { Vidal et al. } \\
2002\end{array}$ \\
\hline K. turgidum & $\begin{array}{l}\text { Present } \\
\text { (good) }\end{array}$ & $\begin{array}{l}\text { White, } 50-55 \mathrm{~mm} \\
\text { (SGA at } 28 \\
\left.{ }^{\circ} \mathrm{C}\right) / \text { pale brown }\end{array}$ & $\begin{array}{l}\text { Pyriform to } \\
\text { oval }\end{array}$ & $\begin{array}{l}5.0-7.0 x \\
3.5-5.0\end{array}$ & Smooth & Present & $\begin{array}{l}\text { Crous et } \\
\text { al. } 2017\end{array}$ \\
\hline
\end{tabular}

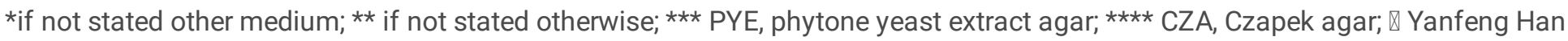
personal communication

Table S1 a Temperature dependent growth of the new Keratinophyton species (in mm) on PDA after 14 days

\begin{tabular}{|c|c|c|c|c|c|c|c|c|c|c|c|c|}
\hline \multirow[t]{2}{*}{ Species } & \multicolumn{12}{|c|}{ Temperature $\left({ }^{\circ} \mathrm{C}\right)$} \\
\hline & $8^{*}$ & 10 & 12 & $15^{\star}$ & 18 & 20 & $25^{\star}$ & 28 & 29 & $30 *$ & $31^{*}$ & 32 \\
\hline $\begin{array}{l}\text { K. } \\
\text { lemmensii }\end{array}$ & $1-2$ & $4-5$ & $7-9$ & $\begin{array}{l}10- \\
14\end{array}$ & - & $\begin{array}{l}25- \\
27\end{array}$ & $\begin{array}{l}28- \\
35\end{array}$ & - & - & $\begin{array}{l}38- \\
45\end{array}$ & $\begin{array}{l}32- \\
38\end{array}$ & $M-1$ \\
\hline K. gollerae & $\begin{array}{l}\text { SG- } \\
M\end{array}$ & $\begin{array}{l}\mathrm{M}- \\
1\end{array}$ & $2-6$ & $\begin{array}{l}15- \\
18\end{array}$ & - & $\begin{array}{l}18- \\
20\end{array}$ & $\begin{array}{l}20- \\
22\end{array}$ & $\begin{array}{l}11- \\
12\end{array}$ & $\begin{array}{l}M- \\
1\end{array}$ & SG & - & - \\
\hline K. straussii & nSG & $1-2$ & $4-5$ & $7-9$ & $\begin{array}{l}18- \\
20\end{array}$ & $\begin{array}{l}18- \\
22\end{array}$ & $\begin{array}{l}24- \\
28\end{array}$ & - & - & $\begin{array}{l}15- \\
20\end{array}$ & $6-8$ & $1-2$ \\
\hline K. wagneri & SG & $1-2$ & $\begin{array}{l}8- \\
10\end{array}$ & $6-8$ & $\begin{array}{l}18- \\
20\end{array}$ & $\begin{array}{l}20- \\
25\end{array}$ & $\begin{array}{l}25- \\
30\end{array}$ & - & - & $3-4$ & $2-3$ & $M-1$ \\
\hline
\end{tabular}

*crucial distinctive growth temperatures; SG, spore germination; nSG, no spore germination; $\mathrm{M}$, microcolonies

Table S1 b Temperature dependent growth of the new Keratinophyton species (in mm) on MEA after 14 days

\begin{tabular}{|lllllllllllll|l|}
\hline Species & \multicolumn{2}{l}{ Temperature $\left({ }^{\circ} \mathrm{C}\right)$} \\
\cline { 2 - 12 } & $8^{*}$ & 10 & 12 & 15 & 18 & 20 & 25 & 28 & 29 & $30^{*}$ & $31^{*}$ & 32 \\
\hline K. lemmensii & $1-2$ & $2-4$ & $5-7$ & $7-10$ & - & $15-17$ & $20-25$ & - & - & $18-20$ & $12-15$ & SG \\
\hline K. gollerae & SG-M & $\mathrm{M}$ & $1-2$ & $5-8$ & - & $10-12$ & $14-16$ & $\mathrm{M}$ & $\mathrm{nSG}$ & - & - & - \\
\hline K. straussii & nSG & $\mathrm{M}$ & $\mathrm{M}$ & $4-7$ & $10-12$ & $10-12$ & $18-20$ & - & - & $5-10$ & $3-4$ & $\mathrm{M}-1$ \\
\hline K. wagneri & $\mathrm{SG}$ & $\mathrm{M}$ & $\mathrm{M}-2$ & $3-5$ & $10-13$ & $12-15$ & $18-20$ & - & - & $\mathrm{M}$ & $\mathrm{M}$ & SG \\
\hline
\end{tabular}

${ }^{*}$ crucial distinctive growth temperatures; SG, spore germination; nSG, no spore germination; M, microcolonies

Table S1 c Temperature dependent growth of the new Keratinophyton species (in mm) on SDA after 14 days

\begin{tabular}{|c|c|c|c|c|c|c|c|c|c|c|c|c|}
\hline \multirow[t]{2}{*}{ Species } & \multicolumn{12}{|c|}{ Temperature $\left({ }^{\circ} \mathrm{C}\right)$} \\
\hline & $8^{*}$ & 10 & 12 & $15^{\star}$ & 18 & 20 & 25 & 28 & 29 & $30 *$ & $31^{*}$ & 32 \\
\hline K. lemmensii & $1-2$ & $6-7$ & $8-10$ & $7-10$ & - & $24-26$ & $28-35$ & - & - & $30-32$ & $25-30$ & $M-1$ \\
\hline K. gollerae & $S G-M$ & $M-1$ & M-1 & $20-22$ & - & $12-17$ & $23-25$ & $M-2$ & SG & SG & $\mathrm{nSG}$ & - \\
\hline K. straussii & nSG & $M-1$ & $2-3$ & $3-4$ & - & $14-16$ & $16-20$ & - & - & $15-20$ & $1-2$ & nSG \\
\hline K. wagneri & SG & $M-1$ & $1-3$ & $3-4$ & - & $12-14$ & $14-18$ & - & - & $M-1$ & $S G-M$ & nSG \\
\hline
\end{tabular}

*crucial distinctive growth temperatures; SG, spore germination; nSG, no spore germination; M, microcolonies 
All four new species are readily distinguished from the other taxa in the genus Keratinophyton, known only as Chrysosporium asexual morphs, based on phenotypical characteristic alone. From the sexual Keratinophyton species, they principally differ by their inability to form ascomata in culture (Cano et al. 2002), but also by overall phenotypic characters, such as growth at high temperature and/or conidial morphology (Cano and Guarro 1990; Cano and Guarro 1994; Currah 1985). The most important species-specific phenotypic distinguishing characteristics are morphology of conidia (shape, surface and dimensions) and growth response to $30^{\circ} \mathrm{C}$ exposure after 14 days on PDA. An identification key for Keratinophyton species modified from Cano et al. (2002) with addition of the new species is provided.

Dichotomous key to the species of Keratinophyton (asexual morphs) modified from Cano et al. (2002).

\begin{tabular}{|c|c|}
\hline \multirow{2}{*}{1} & Conidial surface smooth to finally roughed....................................... 2 \\
\hline & 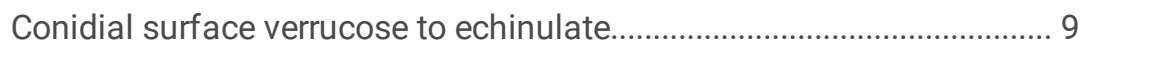 \\
\hline \multirow[t]{3}{*}{$2(1)$} & Growth at $30^{\circ} \mathrm{C}$ absent \\
\hline & 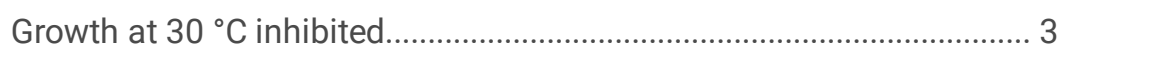 \\
\hline & Growth at $30^{\circ} \mathrm{C}$ present (good) \\
\hline \multirow[t]{2}{*}{$3(2)$} & 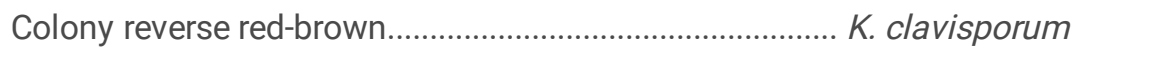 \\
\hline & 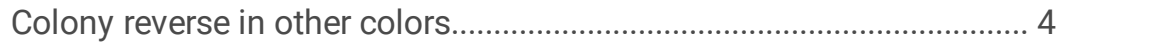 \\
\hline \multirow[t]{2}{*}{$4(3)$} & Intercalary conidia absent, $2.2-4.3 \times 1.6-3.2 \mu \mathrm{m}$ conidia........ K. hubeiense \\
\hline & Intercalary conidia present, $4.0-35 \times 2.5-5.0 \mu \mathrm{m}$ conidia..... K. submersum \\
\hline \multirow[t]{2}{*}{$5(2)$} & Cylindrical to filiform 1- to 2-celled conidia present...................................... 6 \\
\hline & Cylindrical to filiform 1- to 2-celled conidia absent..................................... 7 \\
\hline \multirow[t]{2}{*}{$6(5)$} & Colony white with yellow reverse................................................ lemmensii \\
\hline & Colony griseous orange with brownish reverse............................. K. siglerae \\
\hline \multirow[t]{2}{*}{$7(5)$} & 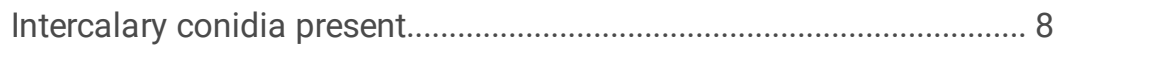 \\
\hline & 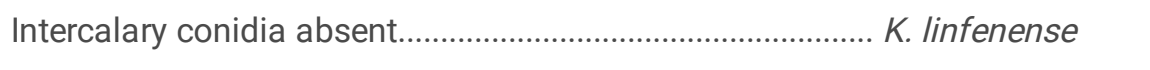 \\
\hline \multirow[t]{2}{*}{$8(7)$} & Clavate to cylindrical conidia, $3.6-13 \times 1.8-3.6 \mu \mathrm{m} . \ldots \ldots \ldots \ldots . . . . . .$. . qinghaiense \\
\hline & 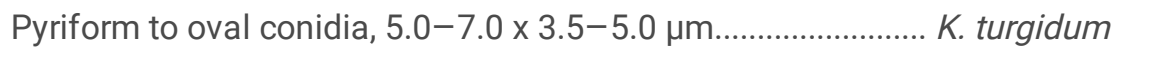 \\
\hline \multirow[t]{2}{*}{$9(1)$} & 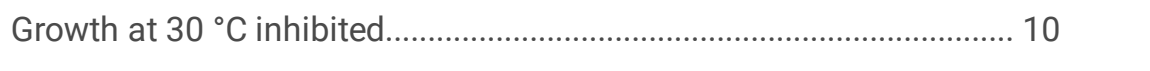 \\
\hline & Growth at $30^{\circ} \mathrm{C}$ present (good) \\
\hline \multirow[t]{2}{*}{$10(9)$} & 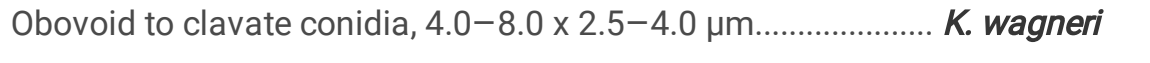 \\
\hline & Pyriform to subglobose conidia, $3.0-4.0 \times 1.5-3.5 \mu \mathrm{m} .$. K. minutisporosum \\
\hline \multirow[t]{2}{*}{$11(9)$} & Colonies yellow to orange, conidia echinulate...................... K. echinulatum \\
\hline & Colonies white to creamy (yellowish), conidia verrucose........................... 12 \\
\hline \multirow[t]{2}{*}{$12(11)$} & Intercalary conidia absent, conidia $4.5-5.0 \times 2.5-3.0 \mu \mathrm{m} \ldots \ldots \ldots . . . . .$. straussii \\
\hline & Intercalary conidia present, conidia more than $5.0 \mu \mathrm{m}$ in length............. 13 \\
\hline \multirow[t]{2}{*}{$13(12)$} & 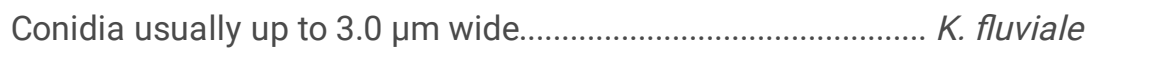 \\
\hline & 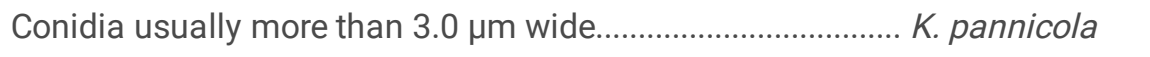 \\
\hline
\end{tabular}


The phylogenetic analyses strongly supported the recent distinct classification of the species previously classified as Chrysosporium asexual morphs into two phylogenetically different sexual genera, namely Aphanoascus and Keratinophyton (Crous et al. 2017; Sutton et al. 2013). In this study, ten new combinations are proposed for Chrysosporium asexual morphs resolved in a monophyletic clade affiliated to the latter genus. Hence, the following Chrysosporium species $C$. clavisporum, $C$. echinulatum, $C$. evolceanui, $C$. fluviale, $C$. hubeiense, $C$. linfenense, $C$. minutisporosum, $C$. siglerae, $C$. submersum and $C$. qinghaiense are revised in the genus Keratinophyton H.S. Randhawa \& R.S. Sandhu.

Keratinophyton clavisporum (Zhang, Han \& Liang) Labuda \& Bernreiter, comb. nov.

Basionym: Chrysosporium clavisporum Zhang, Han \& Liang, Phytotaxa 303: 177 (2017).

Type: G80.1 from plant root soil, China.

MycoBank: MB833653

Keratinophyton echinulatum (Hubka, Mallátová, Cmoková \& Kolařík) Labuda \& Bernreiter, comb. nov.

Basionym: Chrysosporium echinulatum Hubka, Mallátová, Cmoková \& Kolařík, Persoonia 36: 410 (2016).

Type: CCF $4652=$ CBS $141178=$ UAMH 11824, from sole of the foot, Czechia.

MycoBank: MB833636

Keratinophyton pannicola (Corda) Labuda \& Bernreiter, comb. nov.

Basionym: Capillaria pannicola Corda, Icon. Fung. (Prague) 1: 10 (1837).

三Sporotrichum pannicola (Corda) Rabenh., Deutschl. Krypt.-Fl. (Leipzig) 1: 78 (1844)

三 Chrysosporium pannicola (Corda) Oorschot \& Stalpers, Stud. Mycol. 20: 43 (1980)

= Chrysosporium evolceanui (Randhawa \& Sandhu) Garg, Sabouraudia 4: 262 (1966)

= Trichophyton evolceanui Randhawa \& Sandhu, Mycopath. Mycol. Appl. 20: 232 (1963)

Type: CBS $116.63=$ ATCC $22400=$ IHEM $4436=$ IMI $147545=$ NCPF $489=$ RV $26475=$ UAMH 1275, from soil, India. MycoBank: MB8333643

Keratinophyton fluviale (Vidal \& Guarro) Labuda \& Bernreiter, comb. nov.

Basionym: Chrysosporium fluviale Vidal \& Guarro, Mycol. Res. 104: 245 (2000).

Type: CBS 100809 = FMR 6005 =IMI 378764, from river sediments, Spain.

MycoBank: MB8333637

Page $14 / 30$ 
Keratinophyton hubeiense (Zhang, Han \& Liang) Labuda \& Bernreiter, comb. nov.

Basionym: Chrysosporium hubeiense Zhang, Han \& Liang, Phytotaxa 270: 213 (2016).

Type: EM66601, from soil under the chicken feather, China.

MycoBank: MB833638

Keratinophyton linfenense (Liang, Liang \& Han) Labuda \& Bernreiter, comb. nov.

Basionym: Chrysosporium linfenense Liang, Liang \& Han, Mycotaxon 110: 67 (2009).

Type: GZAC H31, from rhizosphere soil, China.

MycoBank: MB833639

Keratinophyton minutisporosum (Vidal \& Guarro) Labuda \& Bernreiter, comb. nov.

Basionym: Chrysosporium minutisporosum Vidal \& Guarro, Stud. Mycol. 47: 205 (2002).

Type: CBS 101577 = FMR 6096 from river mouth sediment, Spain.

MycoBank: MB833640

Keratinophyton siglerae (Cano \& Guarro) Labuda \& Bernreiter, comb. nov.

Basionym: Chrysosporium siglerae Cano \& Guarro, Mycotaxon 51: 75 (1994)

Type: UAMH 6541 = FMR 3066 = IMI 336467, from garden soil, Spain.

MycoBank: MB833641

Keratinophyton submersum (Vidal \& Guarro) Labuda \& Bernreiter, comb. nov.

Basionym: Chrysosporium submersum Vidal \& Guarro, Stud. Mycol. 47: 200 (2002)

Type: CBS 101575 = FMR 6088, from river mouth sediment, Spain

MycoBank: MB833642

Keratinophyton qinghaiense (Han, Wang, Liang \& Liang) Labuda \& Bernreiter, comb. nov.

Basionym: Chrysosporium qinghaiense Han, Wang, Liang \& Liang, Mycosystema 32: 607 (2013).

Type: GZUIFR 11, from farmland soil, China.

MycoBank: MB833655

Page $15 / 30$ 


\section{Discussion}

\section{Phylogeny}

Phylogenetic reconstruction using ITS sequences resulted in clustering of a new species, Keratinophyton lemmensii, with $K$. durum (as Aphanoascus durus; Cano and Guarro 1990), K. hubeiense (as Chrysosporium hubeiense; Zhang et al. 2016) and K. submersum (as Chrysosporium submersum; Vidal et al. 2002), and forming a sister clade to K. siglerae (as Chrysosporium siglerae, Cano and Guarro 1994). The other three novel species, K. gollerae, K. straussii and K. wagneri were resolved in a separate terminal clade (Fig 1a). Its sister clade similarly encompasses mostly asexual Chrysosporium morphs belonging to $K$. clavisporum (as Chrysosporium clavisporum; Zhang et al. 2017), K. quinghaense (as Chrysosporium quinghaense, Han et al. 2013), K. linfenense (as Chrysosporium linfenense, Liang et al. 2009) and K. turgidum (Crous et al., 2017). Based on the phylogeny and due to the one-fungus one name concept (Taylor 2011), asexual morphs are now placed in genera conventionally comprising only sexual morphs (Crous et al. 2017). Hence, by following this concept also in this study, the generic name Keratinophyton is chosen to represent new taxa instead of Chrysosporium. As pointed out by Crous et al. (2017), the monophyletic Keratinophyton clade contains several asexual species which have Chrysosporium morph, and require redisposing in the genus Keratinophyton. Likewise, they introduced a new asexual species, Keratinophyton turgidum Rahul Sharma \& Shouche. Current study results were found compatible with the previous reports in terms of the phylogenetic positions of $K$. clavisporum, K. echinulatum, K. fluviale, K. hubeiense, K. linfenense, K. minutisporosum, K. pannicola, K. siglerae, K. submersum and K. qinghaiense (Crous et al. 2017; Li et al. 2019; Sutton et al. 2013; Zhang et al. 2016; Zhang et al. 2017). Therefore, we use this as justification to revise ten asexual morphs previously described in the genus Chrysosporium. At the time of the present study, the monophyletic genus Keratinophyton has been shown containing six sexual (Sutton et al. 2013) and 15 species (asexual morphs), including recently described K. turgidum (Crous et al. 2017) and four novel taxa described here. Each of these asexual morphs can be distinguished from each other by particular combination of their morphological traits (the colony color and growth rate, growth response on higher/lower temperature as well as morphology of conidia) and differences in ITS regions (Fig. 1a, Table 2).

\section{Ecology and Distribution}

Almost all known Keratinophyton species were isolated from soil or soil-like substrates, such as river sediment, compost and sand (Table 1) (Cano and Guarro 1990; Crous et al. 2017; Labuda et al. 2008; Liang et al. 2009; Oorschot 1980; Vidal et al. 2000; Vidal et al. 2002). Hubalek (2000) provided a list of keratinolytic fungi associated with free-living mammals and birds of which Keratinophyton pannicola (as Chrysosporium evolceanui) has been isolated from a variety of animals, namely from different species of rodents in Australia, Czechia, England, Germany, former Yugoslavia; from a rabbit in Canada, and from birds in Czechia, Queensland, former Yugoslavia and India. Keratinophyton durum (as Aphanoascus durus) has been isolated from a hedgehog in Ivory Coast, and Keratinophyton terreum (as Aphanoascus terreus) has been found associated with a variety of rodents in Romania, Germany, India, Czechia, former Yugoslavia and Nigeria, and birds in Czechia, former Yugoslavia, India, Queensland and USA (Hubalek 2000). To the best of our knowledge, only a single report dealing with a human clinical isolate is the type strain $K$. echinulatum (CCF 4652 = CBS 141178) from the sole of the foot of a 35-years-old woman in the Czechia (Crous et al. 2016). However, same authors indicated that the etiological significance of this fungus is unclear, and they concluded that the infection was in fact caused by a dermatophyte, which was not isolated or overgrown by $K$. echinulatum. A few other cases have been published in a small range of animals including Keratinophyton pannicola (as Chrysosporium pannicola) from affected skin of a dog in former Yugoslavia (Hajsig et al. 1974; Oorschot 1980) and from a case of keratomycosis in a horse (Grahn et al. 1993). In her review on Chrysosporium and related genera in Onygenaceae, Sigler (2003) stated that some reports concerning Chrysosporium species as etiological agents must be viewed with caution, in case the isolated fungus has neither been identified to species level nor documented well enough to confirm the etiology. In the follow up list of medically relevant species provided by Sigler (2003), there is no species mentioned being currently affiliated within the genus Keratinophyton while K. pannicola (as C. pannicola) was reported in Atlas of Clinical Fungi (de Hoog et al. 2020) as a concern of skin infections. On the other hand, according to Papini et al. (1998), every keratinophilic fungus can be considered a potential pathogen. Thus, soil can be regarded as an epidemiological link, probably evolutionary as well, that relates geophilic, zoophilic, and anthropophilic keratinophilic fungi. As a matter of fact, during a mycological investigation of the soil samples in the present study, a high

Page $16 / 30$ 
prevalence of geophilic dermatophytes such as Nannizzia gypsea from Italy (collected in 2004), co-occurrence of Arthroderma uncinatum with Aphanoascus keratinophilus (as Chrysosporium keratinophilum) from Slovak Repuplic (collected in 2011), and Arthroderma terrestre along with abundant $A$. uncinatum in a from Austria (collected in 2015) was noted (data not shown).

As the members of the genus Keratinophyton are considered as typical soilborne fungi (Cano and Guarro 1990; Cano et al. 2002; Sutton et al. 2013) and there is no solid evidence of pathogenicity, it is likely that previously reported animal-associated cases reflect environmental transmissions from soil to the animals during their activities when they are in contact with soil. The ability of these fungi to persist and survive in the soil was observed also during the present study, as in case of $K$. straussii, the ex-type culture (BiMM-F78) was isolated 11 years after the sampling in 2004, and two more strains (RL-05 and RL-06) representing the same taxon were isolated in a repeated study even 15 years after the sampling. Likewise, a second strain (RL-07) used for description of $K$. wagneri and the ex-type culture of $K$. gollerae (BiMM-F250) were both isolated 8 years after collecting the samples.

In this study, the degree of keratin degradation by the novel strains varied and was found to be very strong in both $K$. gollerae and K. straussii compare to other tested strains, by their evoking attack on cuticle and cortex with about $50-80 \%$ degradation of the hair. In addition to keratin degradation, keratinolytic fungi share common properties with dermatophytes (Marchisio et al. 1994; Mitola et al. 2002). Even though some of these fungi can grow at $37^{\circ} \mathrm{C}$ (Fig. 1a), potential pathogenicity to homeothermic vertebrates (mammals and birds) by these fungi seems highly unlikely possibly because of some missing pathways in their metabolism. Instead, their strong keratinolytic ability might be providing a competitive advantage in the nature to acquire nutrients and may also potentially be used in industry for production of proteolytic enzymes applied in degradation processes of keratinous material (hairs, fur, feather etc.). Furthermore, these fungi represent yet undiscovered source of new bioactive secondary metabolites as there is not much known from the literature about these properties of the genus (Kushwaha and Guarro 2000). Therefore, further studies will be provided to investigate secondary metabolite profiles of the new species described in the present study.

\section{Conclusions}

The study describes four novel species of the genus Keratinophyton isolated from a compost soil sample in Austria ( $K$. lemmensii), a garden sample in Italy (K. straussii), and a forest soil sample in the Slovak Republic (K. gollerae and $K$. wagneri). The new taxa can be distinguished from the other taxa in the genus by phylogenetic analysis of ITS region as well as by their phenotype. A dichotomous key and a compilation of the most distinguishing traits within the species accepted in the genus Keratinophyton is provided. Ten new combinations are proposed for Chrysosporium asexual morphs which are resolved in the monophyletic Keratinophyton clade. All novel species will be further investigated for their ability to produce bioactive secondary metabolites.

\section{Abbreviations}

A: Aphanoascus; AT: Austria, BiMM: Bioactive Microbial Metabolites group; C. Chrysosporium; CBS: Centraalbureau voor Schimmelcultures (in Westerdijk Fungal Biodiversity Institute), CCF: Culture Collection of Fungi; CMA: Corn Meal Agar; CTAB: cetyltrimethyl ammonium bromide; Ct. Ctenomyces, CZ: Prague; FMR: Facultat de Medicina in Ciències de la Salut; IFO: Institute for Fermentation, Osaka; IMI: International Mycological Institute; ITS: Internal transcribed spacer region; LSU: Nuclear large subunit rDNA; M: microcolonies; ML: Maximal likelihood; MEA: Malt Extract Agar; NBRC: NITE Biological Resource Center, Japan; nSG: no spore germination; PCR: Polymerase chain reaction; PCA: Potato Carrot Agar; PDA: Potato Dextrose Agar; PRM:

Mycological Department, National Museum, Prague, Czech Republic; rDNA: ribosomal DNA; SEM: Scanning electron microscopy; SDA: Sabouraud 4\% Dextrose Agar; SG: spore germination; UAMH: University of Alberta Microfungus Collection and Herbarium; YEW: water with 2-3 drops of $10 \%$ yeast extract

\section{Declarations}

\section{Acknowledgements}

Page 17/30 
We thank Paul N. Schüller for providing hair samples and our thanks also go to Dr. Miroslav Hyliš for assistance with scanning electron microscopy. We thank Dr. Vít Hubka for his assistance in interpretation of phylogenetic trees and Dr. Huzefa Raja for revision of the English text.

\section{Authors' Contributions}

RL performed isolation and phenotypic research with the novel fungi and fungal illustration (line drawings). $A B, D H$ and $H K$ performed molecular and phylogenetic analyses. AK performed all microscopical measurements and provided the microphotography (including SEM). The manuscript was written by RL and CS. Final revision of the manuscript was done by HK. All authors read and approved the final manuscript.

\section{Funding}

The Bioactive Microbial Metabolites research platform (BiMM) is supported by grants K3-G-2/026-2013 and COMBIS/ LS16005 funded by the Lower Austria Science and Education Fund (NfB).

\section{Availability of data and materials}

The data analyzed in this study are available from the corresponding author on reasonable request.

\section{Ethics approval and consent to participate}

Not applicable.

\section{Consent for publication}

Not applicable.

\section{Competing interests}

The authors declare that they have no competing interests.

\section{References}

Anbu P, Hilda A, Gopinath SC (2004) Keratinophilic fungi of poultry farm and feather dumping soil in Tamil Nadu, India Mycopathologia 158:303-309. doi:10.1007/s11046-004-3465-1

Atlas, RM (1946) Handbook of microbiological media (3 ${ }^{\text {rd }}$ edition). CRC Press, USA. 1706 pp.

Cabanes FJ, Sutton DA, Guarro J (2014) Chrysosporium-related fungi and reptiles: a fatal attraction PLoS Pathogens 10:e1004367. doi:10.1371/journal.ppat.1004367

Cano J, Guarro J (1990) The genus Aphanoascus Mycological Research 94(3):355-377

Cano J, Guarro J (1994) Studies on keratinophilic fungi. III. Chrysosporium siglerae sp. nov. Mycotaxon 51:75-79

Cano J, Sagués M, Barrio E, Vidal P, Castañeda RF, Gené J, Guarro J (2002) Molecular taxonomy of Aphanoascus and description of two new species from soil. Studies in Mycology 47:153-164

Chmel L, Vláčilíková A (1977) Keratinophilic fungi in some types of soil and factors influencing their occurrence. Biologia 32:5359

Crous PW, Wingfield MJ, Burgess TI, Hardy G, Barber PA, P. Alvarado, C. W. Barnes, P. K. Buchanan, M. Heykoop, G. Moreno, R. Thangavel, S. van der Spuy, A. Barili, S. Barrett, S. O. Cacciola, J. F. Cano-Lira, C. Crane, C. Decock, T. B. Gibertoni, J. Guarro, M. Guevara-Suarez, V. Hubka, M. Kolarik, C. R. S. Lira, M. E. Ordonez, M. Padamsee, L. Ryvarden, A. M. Soares, A. M. Stchigel, D. A. Sutton, A. Vizzini, B. S. Weir, K. Acharya, F. Aloi, I. G. Baseia, R. A. Blanchette, J. J. Bordallo, Z. Bratek, T. Butler, J. Cano-Canals, J. 
R. Carlavilla, J. Chander, R. Cheewangkoon, R. Cruz, M. da Silva, A. K. Dutta, E. Ercole, V. Escobio, F. Esteve-Raventos, J. A. Flores, J. Gene, J. S. Gois, L. Haines, B. W. Held, M. H. Jung, K. Hosaka, T. Jung, Z. Jurjevic, V. Kautman, I. Kautmanova, A. A. Kiyashko, M. Kozanek, A. Kubatova, M. Lafourcade, F. La Spada, K. P. D. Latha, H. Madrid, E. F. Malysheva, P. Manimohan, J. L. Manjon, M. P. Martin, M. Mata, Z. Merenyi, A. Morte, I. Nagy, A. C. Normand, S. Paloi, N. Pattison, J. Pawlowska, O. L. Pereira, M. E. Petterson, B. Picillo, K. N. A. Raj, A. Roberts, A. Rodriguez, F. J. Rodriguez-Campo, M. Romanski, M. Ruszkiewicz-Michalska, B. Scanu, L. Schena, M. Semelbauer, R. Sharma, Y. S. Shouche, V. Silva, M. Staniaszek-Kik, J. B. Stielow, C. Tapia, P. W. J. Taylor, M. ToomeHeller, J. M. C. Vabeikhokhei, A. D. van Diepeningen, N. Van Hoa, V. T. M, N. P. Wiederhold, M. Wrzosek, J. Zothanzama, and J. Z. Groenewald. 2016. Chrysosporium echinulatum Hubka, Mallátová, Cmokova \& Kolarik, sp. nov. Persoonia 38:446.

Crous, P. W., M. J. Wingfield, T. I. Burgess, G. Hardy, P. A. Barber, P. Alvarado, C. W. Barnes, P. K. Buchanan, M. Heykoop, G. Moreno, R. Thangavel, S. van der Spuy, A. Barili, S. Barrett, S. O. Cacciola, J. F. Cano-Lira, C. Crane, C. Decock, T. B. Gibertoni, J. Guarro, M. Guevara-Suarez, V. Hubka, M. Kolarik, C. R. S. Lira, M. E. Ordonez, M. Padamsee, L. Ryvarden, A. M. Soares, A. M. Stchigel, D. A. Sutton, A. Vizzini, B. S. Weir, K. Acharya, F. Aloi, I. G. Baseia, R. A. Blanchette, J. J. Bordallo, Z. Bratek, T. Butler, J. Cano-Canals, J. R. Carlavilla, J. Chander, R. Cheewangkoon, R. Cruz, M. da Silva, A. K. Dutta, E. Ercole, V. Escobio, F. Esteve-Raventos, J. A. Flores, J. Gene, J. S. Gois, L. Haines, B. W. Held, M. H. Jung, K. Hosaka, T. Jung, Z. Jurjevic, V. Kautman, I. Kautmanova, A. A. Kiyashko, M. Kozanek, A. Kubatova, M. Lafourcade, F. La Spada, K. P. D. Latha, H. Madrid, E. F. Malysheva, P. Manimohan, J. L. Manjon, M. P. Martin, M. Mata, Z. Merenyi, A. Morte, I. Nagy, A. C. Normand, S. Paloi, N. Pattison, J. Pawlowska, O. L. Pereira, M. E. Petterson, B. Picillo, K. N. A. Raj, A. Roberts, A. Rodriguez, F. J. Rodriguez-Campo, M. Romanski, M. Ruszkiewicz-Michalska, B. Scanu, L. Schena, M. Semelbauer, R. Sharma, Y. S. Shouche, V. Silva, M. Staniaszek-Kik, J. B. Stielow, C. Tapia, P. W. J. Taylor, M. ToomeHeller, J. M. C. Vabeikhokhei, A. D. van Diepeningen, N. Van Hoa, V. T. M, N. P. Wiederhold, M. Wrzosek, J. Zothanzama, and J. Z. Groenewald. 2017. Keratinohyton turgidum Rahul Shama, \& Shouche, sp. nov. Persoonia 38:341

Currah RS (1985) Taxonomy of the onygenales: Arthrodermataceae, Gymnoscaceae; Myxotrichaceae and Onygenaceae. Mycotaxon 24:1-216

de Hoog GS, Guarro JG, Gené J, Ahmed S, Al-Hatmi AMS, Figueras MJ, Vitale RG (2020) Atlas of clinical fungi. 4th ed. Utrecht: Foundation Atlas of Clinical Fungi, Hilversum.

Deshmukh SK (2004) Isolation of dermatophytes and other keratinophilic fungi from the vicinity of salt pan soils of Mumbai, India. Mycopathologia 157(3):265-267. doi:10.1023/b:myco.0000024174.69248.8d

Deshmukh SK, Mandeel QA, Verekar SA (2008) Keratinophilic fungi from selected soils of Bahrain. Mycopathologia 165(3):143147. doi:10.1007/s11046-007-9067-y

Doyle JJ, Doyle JL (1987) A rapid DNA isolation procedure for small quantities of fresh leaf tissue. Phytochemical Bulletin 19(1):11-15

Gardes M, Bruns TD (1993) ITS primers with enhanced specificity for basidiomycetes-application to the identification of mycorrhizae and rusts. Molecular Ecology 2(2):113-118.

Grahn B, Wolfer J, Keller C, Wilcock B (1993) Equine keratomycosis: clinical and laboratory findings in 23 cases. Progress in Veterinary \& Comparative Ophthalmology 3: 2-7.

Gouy M, Guindon S, Gascuel O (2010) SeaView version 4: A multiplatform graphical user interface for sequence alignment and phylogenetic tree building. Molecular Biology and Evolution 27(2):221-224. doi:10.1093/molbev/msp259

Hajsig M, Vries GA de, Sertic V, Naglic T (1974) Chrysosporium evolceanui from pathologically changed dog skin. Veterinarski Arhiv 44: 209-211.

Han Y, Wang Y, Liang J, Liang Z (2013) A new species of the genus Chrysosporium from the farmland soil of Qinghai Province. Mycosystema 32(4):606-611 
Hubalek Z (2000) Keratinophilic fungi associated with free-living mammals and birds. In: Biology of dermatophytes and other keratinophilic fungi. Revista Iberoamericana de Micología, Bilbao (Spain). pp. 93-103

Javorekova S, Labuda R, Makova J, Novak J, Medo J, Majercikova K (2012) Keratinophilic fungi isolated from soils of long-term fold-grazed, degraded pastures in national parks of Slovakia. Mycopathologia 174(3):239-245. doi:10.1007/s11046-012-9543-X

Kushwaha RK, Guarro J (2000) Biology of dermatophytes and other keratinophilic fungi. Revista Iberoamericana de Micologia, Bilbao (Spain)

Labuda R, Nad'ová L, Vén T (2008) First record of Chrysosporium europae, Ch. fluviale and Ch. minutisporosum in Slovakia. Biologia 63(1):38-39. doi:10.2478/s11756-008-0013-3

Larkin MA, Blackshields G, Brown NP, Chenna R, McGettigan PA, McWilliam H, Valentin F, Wallace IM, Wilm A, Lopez R, Thompson JD, Gibson TJ, Higgins DG (2007) Clustal W and Clustal X version 2.0. Bioinformatics 23(21):2947-2948. doi:

10.1093/bioinformatics/btm404.

Letunic I, Bork P (2019) Interactive Tree Of Life (iTOL) v4: recent updates and new developments. Nucleic Acids Research 47(W1): W256-W259.

Li Z, Zhang Y-W, Chen W-H, Han Y-F (2019) Morphological traits and molecular analysis for two new Chrysosporium species from Fujian Province, China. Phytotaxa 400(5):257-264. doi:10.11646/phytotaxa.400.5.1

Liang J, Yanfeng H, Wen D, Zongqi L, Zizhong L (2009) Chrysosporium linfenense: a new Chrysosporium species with keratinolytic activity. Mycotaxon 110:65-71.

Marchisio VF, Fusconi A, Rigo S (1994) Keratinolysis and its morphological expression in hair digestion by airborne fungi. Mycopathologia 127(2):103-115.

Mori Y, Sato Y, Takamatsu S (2000) Evolutionary analysis of the powdery mildew fungi using nucleotide sequences of the nuclear ribosomal DNA. Mycologia 92(1):74-93.

Page RDM (1996) TREEVIEW: An application to display phylogenetic trees on personal computers. Computer Applications in the Biosciences 12(4): 357-358.

Papini R, Mancianti F, Grassotti G, Cardini G (1998) Survey of keratinophilic fungi isolated from city park soils of Pisa, Italy. Mycopathologia 143(1):17-23. doi:10.1023/a:1006919707839

Ronquist F, Huelsenbeck JP (2003) MrBayes 3: Bayesian phylogenetic inference under mixed models. Bioinformatics 19(12): 1572-1574.

Samson RA, Houbraken J, Thrane U, Frisvad JC, Andersen B (2010) Food and indoor fungi. In: CBS Laboratory Manual Series. CBS-KNAW Fungal Biodiversity Centre Utrecht, The Netherlands, p 10.

Samson RA, Stalpers JA, Verkerke W (1979) A simplified technique to prepare fungal specimens for scanning electron microscopy. Cytobios 24(93):7-11.

Sigler L (2003) Miscellaneous opportunistic fungi. In: Howard DH (ed) Pathogenic Fungi in Humans and Animals. Marcel Dekker, Inc., New York, pp 637-676.

Singh I, Kushwaha RKS, Parihar P (2009) Keratinophilic fungi in soil of potted plants of indoor environments in Kanpura, India, and their proteolytic ability. Mycoscience 50(4):303-307.

Sutton DA, Marín Y, Thompson EH, Wickes BL, Fu J, García D, Swinford A, de Maar T, Guarro J (2013) Isolation and characterization of a new fungal genus and species, Aphanoascella galapagosensis, from carapace keratitis of a Galapagos tortoise (Chelonoidis nigra microphyes). Medical Mycology 51(2):113-120. doi:10.3109/13693786.2012.701767

Page 20/30 
Taylor JW (2011) One Fungus = One Name: DNA and fungal nomenclature twenty years after PCR. IMA Fungus 2:113-120.

Trifinopoulos J, Nguyen LT, von Haeseler A, Minh BQ (2016) W-IQ-TREE: a fast online phylogenetic tool for maximum likelihood analysis. Nucleic Acids Research 44(W1): W232-W235.

Ulfig K, Guarro J, Cano J, Gené J, Vidal P, Figueras MJ, Łukasik W (1997) The occurrence of keratinolytic fungi in sediments of the river Tordera (Spain). FEMS Microbiology Ecology 22(2):111-117.

van Oorschot CAN (1980) A revision of Chrysosporium and allied genera. Studies in Mycololgy 1:1-89

Vidal P, Sanchez-Puelles JM, Milan D, Guarro J (2000) Chrysosporium fluviale, a new keratinophilic species from river sediments. Mycological Research 104(2):244-250. doi:https://doi.org/10.1017/S0953756299001082

Vidal P, Valmaseda M, Vinuesa MÁ, Guarro J (2002) Two new species of Chrysosporium. Studies in Mycology 47:199-210.

Vidyasagar GM, Hosmani N, Shivkumar D (2005) Keratinophilic fungi isolated from hospital dust and soils of public places at Gulbarga, India. Mycopathologia 159(1):13-21. doi:10.1007/s11046-004-9483-1

White TJ, Bruns T, Lee S, Taylor JW (1990) Amplification and direct sequencing of fungal ribosomal RNA genes for phylogenetics. In: Innis MA, Gelfand DH, Sninsky JJ, White T J (eds) PCR Protocols: A Guide to Methods and Applications. Academic Press Inc, New York, pp 315-322

Zaki SM, Mikami Y, Karam El-Din AA, Youssef YA (2005) Keratinophilic fungi recovered from muddy soil in Cairo vicinities Egypt. Mycopathologia 160(3):245-251.

Zhang Y-W, Chen W, Zeng G, Zou X, Wen T, Han Y, Qiu S-Y, Liang Z-Q (2016) Two new Chrysosporium (Onygenaceae, Onygenales) from China. Phytotaxa 270(3):210-216. doi:10.11646/phytotaxa.270.3.5

Zhang Y-W, Zeng G-P, Zou X, Han Y-F, Liang Z-Q, Qui S-Y (2017) Two new keratinophilic fungal species. Phytotaxa 303(2):173180. doi:10.11646/phytotaxa.303.2.7

\section{Figures}
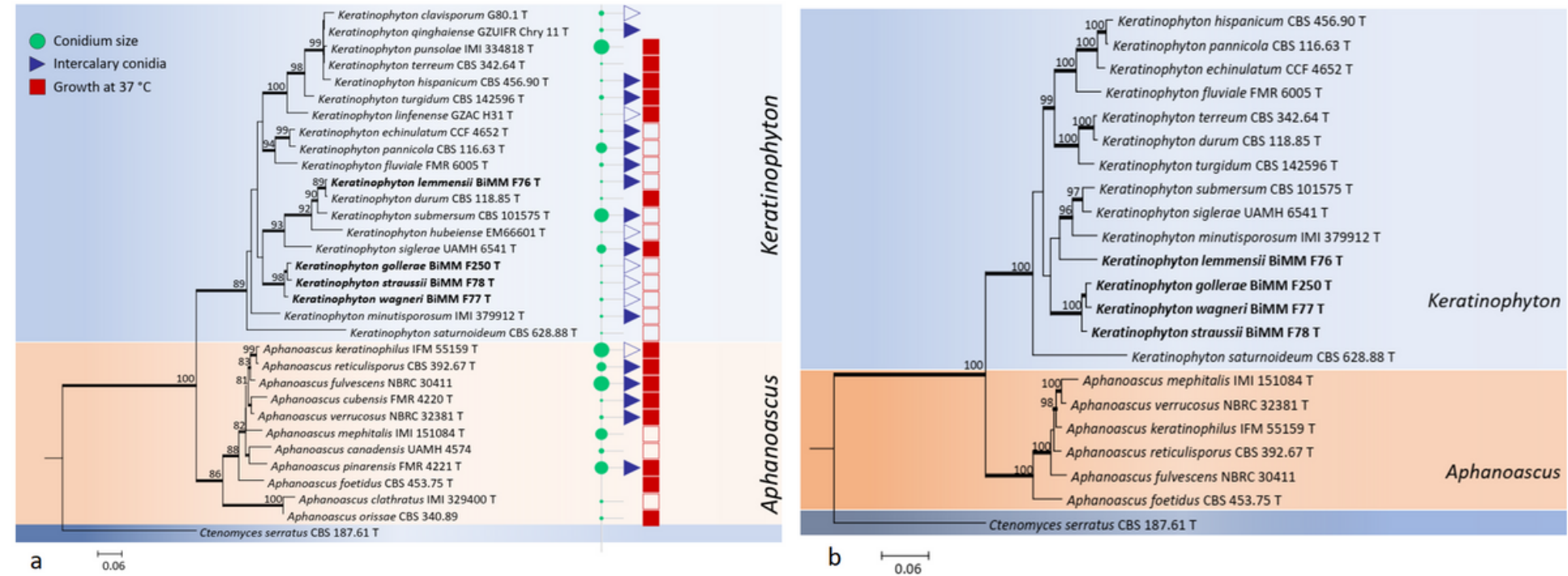

Figure 1

a Maximum Likelihood (ML) tree based on ITS sequence for the new taxa of Keratinophyton is compared with available sequences of the other related species as well as their conidium size, presence of intercalary conidia and ability to grow at $37^{\circ} \mathrm{C}$. 
Numbers at nodes indicate bootstrap values. Ctenomyces serratus was used as outgroup. A sequence for K. multiporum was not available for the study. T, type strain. New species are shown in bold. b. Bayesian interference tree based on combination of ITS and LSU rDNA sequences for new taxa of Keratinophyton together with available sequences of the other related species. Numbers at nodes indicate bootstrap values. Ctenomyces serratus was used as outgroup. New species are shown in bold.

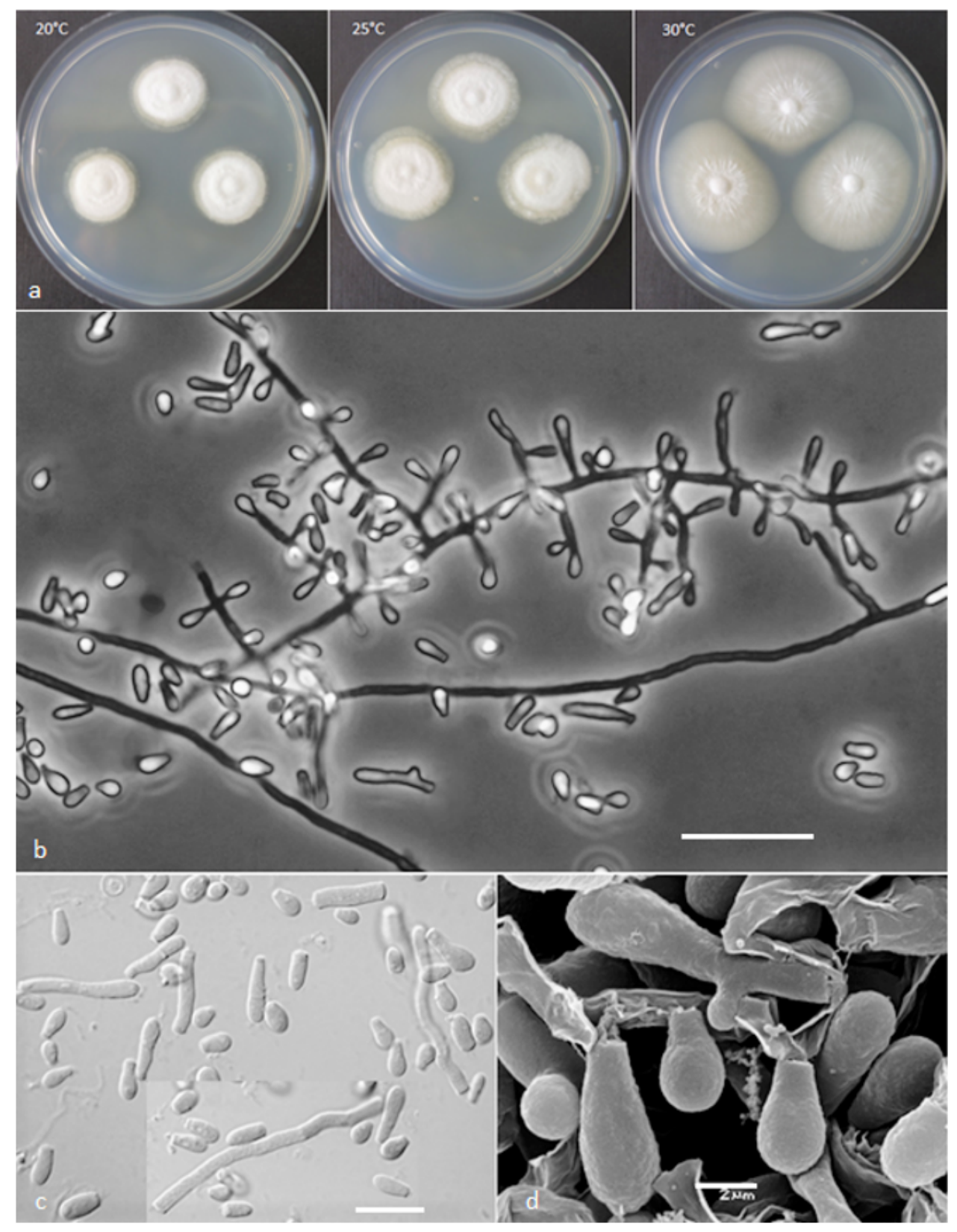

\section{Figure 2}

Keratinophyton lemmensii (BiMM-F76). a Colonies on PDA (after 14 days) at $20^{\circ} \mathrm{C}, 25^{\circ} \mathrm{C}$ and $30^{\circ} \mathrm{C}$. b Conidiophores with aleurioconidia. c Aleurioconidia and arthroconidia (on PDA, after 14 days). d Scanning electron microscopy (SEM) of aleurioconidia (on PDA, after 14 days). Bars $=20 \mu \mathrm{m}$ (b), $10 \mu \mathrm{m}$ (c), $2 \mu \mathrm{m}$ (d) 


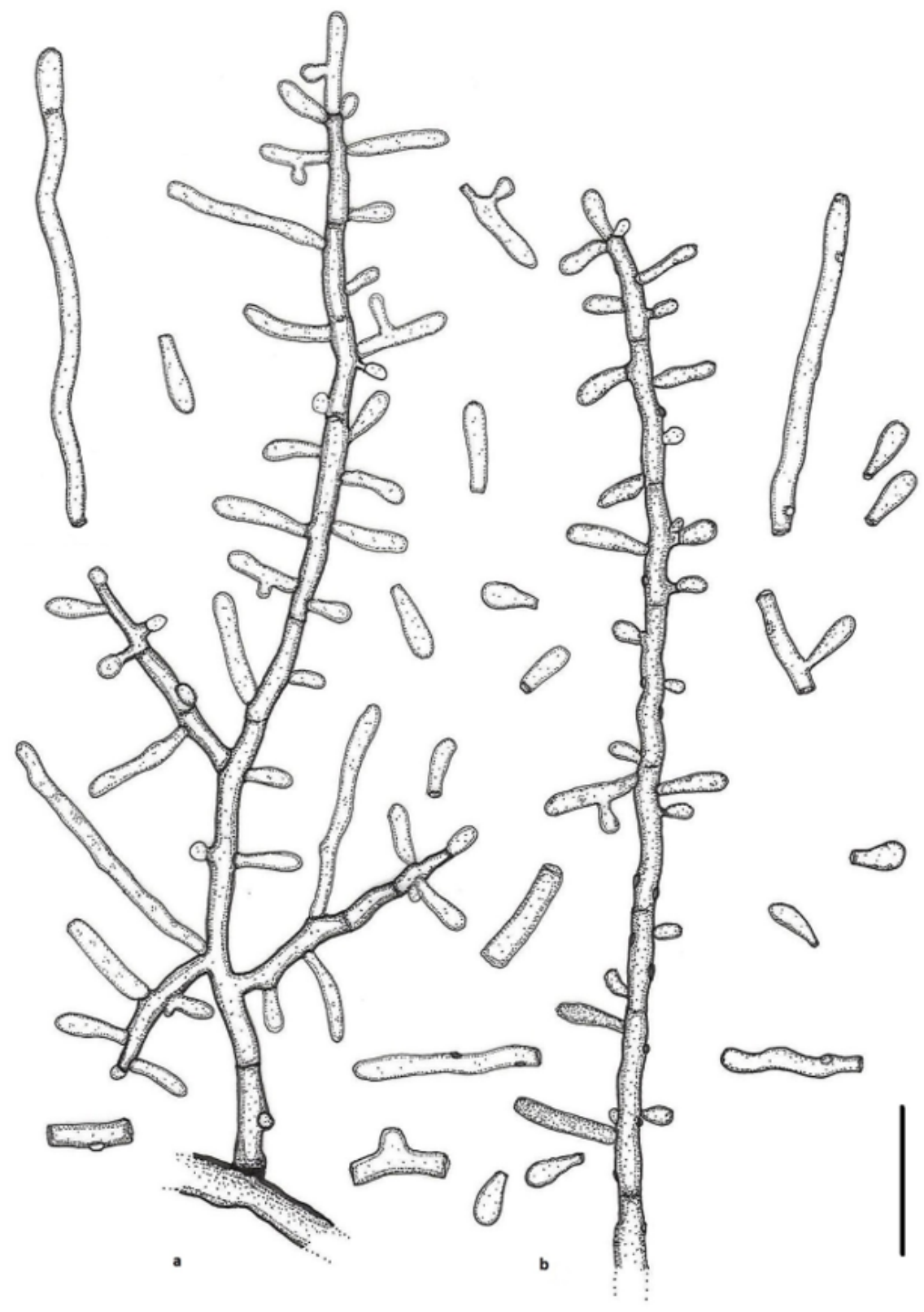

Figure 3

Line drawing of micromorphology of Keratinophyton lemmensii (BiMM-F76). a, b Conidiophores with young and mature aleurioconidia, including arthroconidia on PDA (after 14 days). a Branched conidiophore. b Unbranched conidiophore with sessile aleurioconidia. Bar $=10 \mu \mathrm{m}$ 

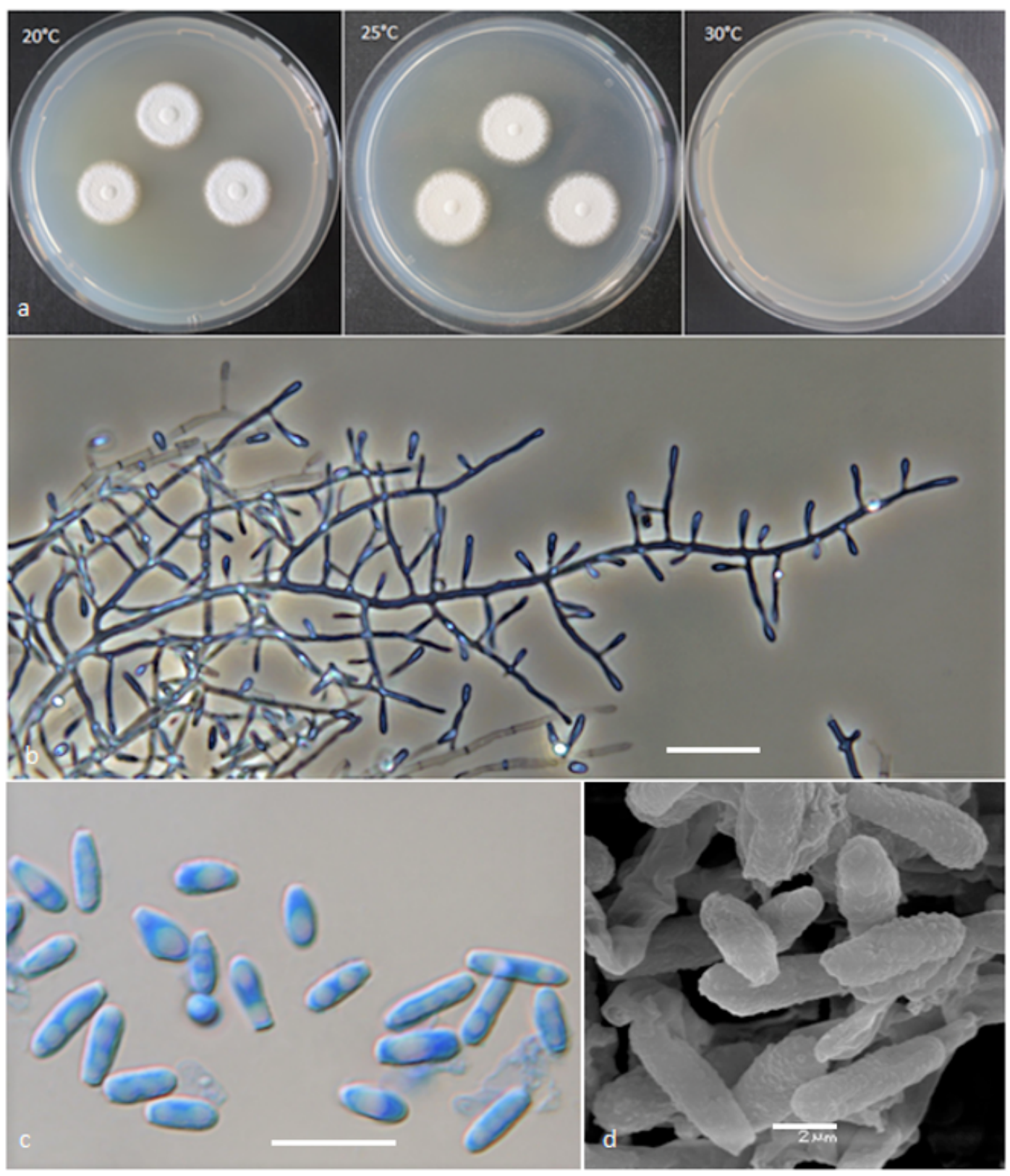

\section{Figure 4}

Keratinophyton gollerae (BiMM-F250). a Colonies on PDA (after 14 days) at $20^{\circ} \mathrm{C}, 25^{\circ} \mathrm{C}$ and $30^{\circ} \mathrm{C}$. b Conidiophores with aleurioconidia. c Aleurioconidia and arthroconidia (on PDA, after 14 days). d Scanning electron microscopy (SEM) of aleurioconidia (on PDA, after 14 days). Bars $=20 \mu \mathrm{m}$ (b), $10 \mu \mathrm{m}$ (c), $2 \mu \mathrm{m}$ (d) 


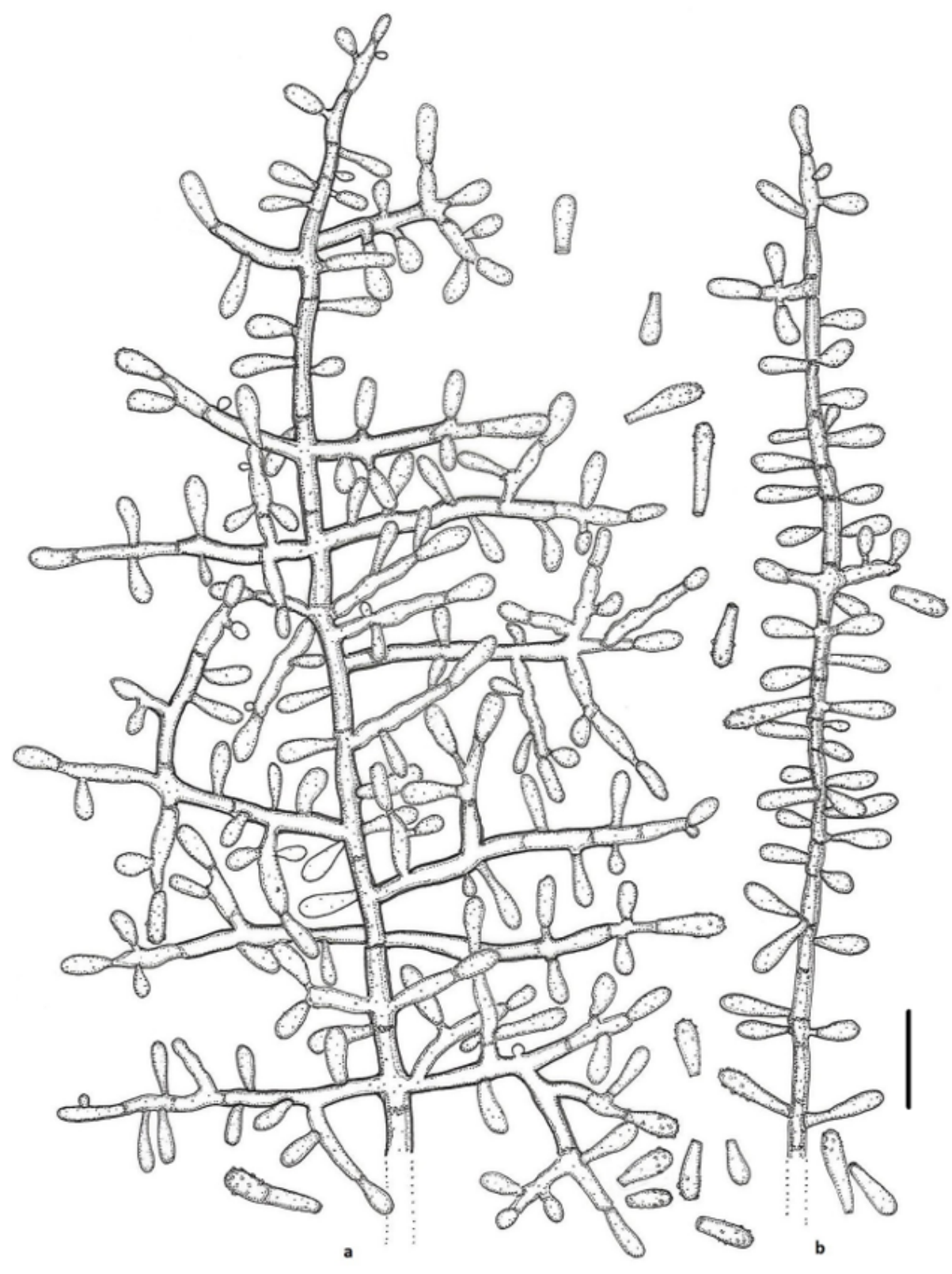

Figure 5

Line drawing of micromorphology of Keratinophyton gollerae (BiMM-F250). a, b Conidiophores with young and mature aleurioconidia on PDA (after 14 days). a Branched conidiophore. $\mathrm{b}$ Unbranched conidiophore with sessile aleurioconidia. Bar $=10$ $\mu \mathrm{m}$ 


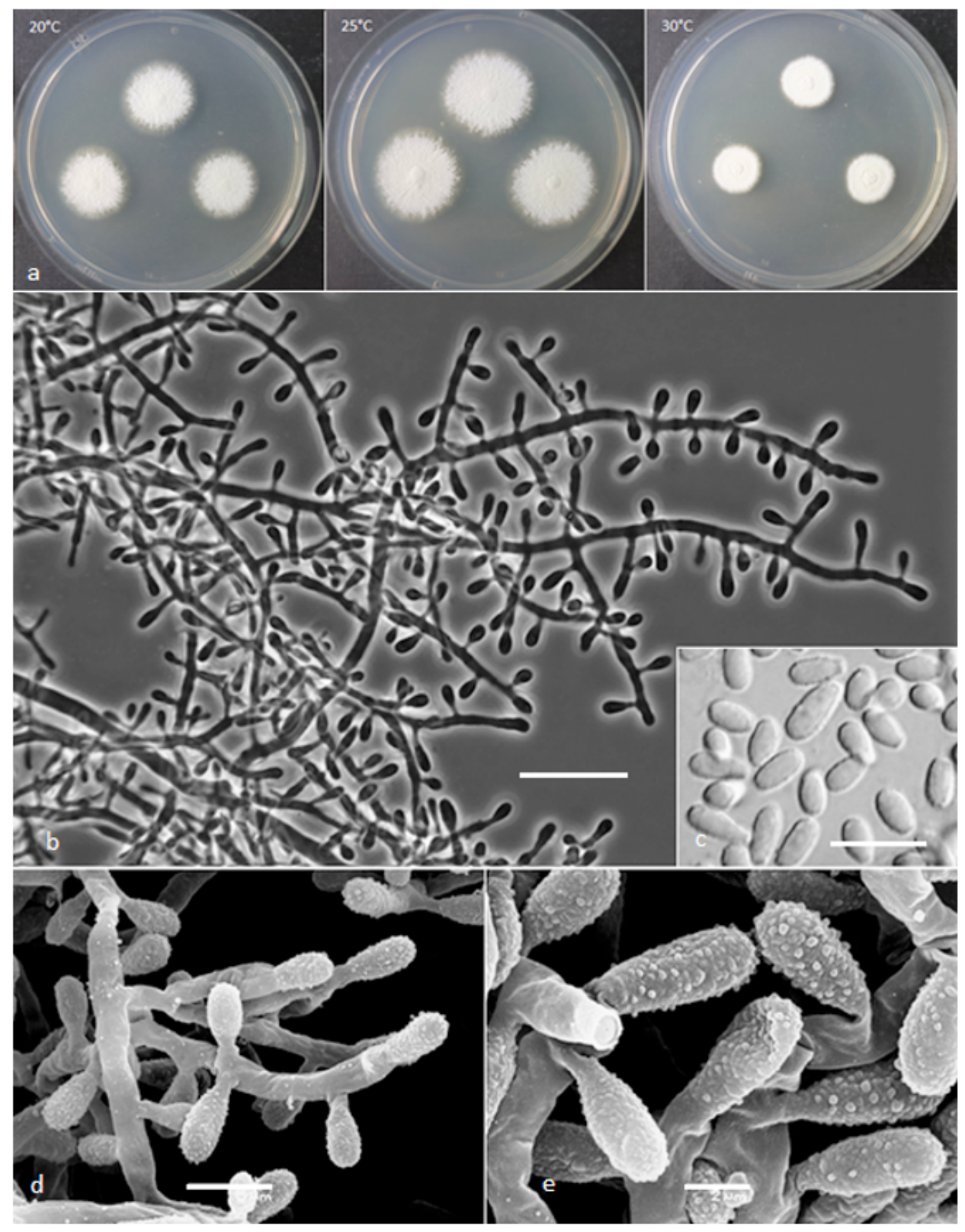

\section{Figure 6}

Keratinophyton straussii BiMM-F78. a Colonies on PDA (14 days old) at $20^{\circ} \mathrm{C}, 25^{\circ} \mathrm{C}$ and $30^{\circ} \mathrm{C}$. b Conidiophores with aleurioconidia. c Aleurioconidia (on PDA, after 14 days). d, e Scanning electron microscopy (SEM) of conidiogenous cells and aleurioconidia (on PDA, after 14 days). Bars $=20 \mu \mathrm{m}$ (b), $10 \mu \mathrm{m}$ (c), $5 \mu \mathrm{m}$ (d), $2 \mu \mathrm{m}$ (e) 


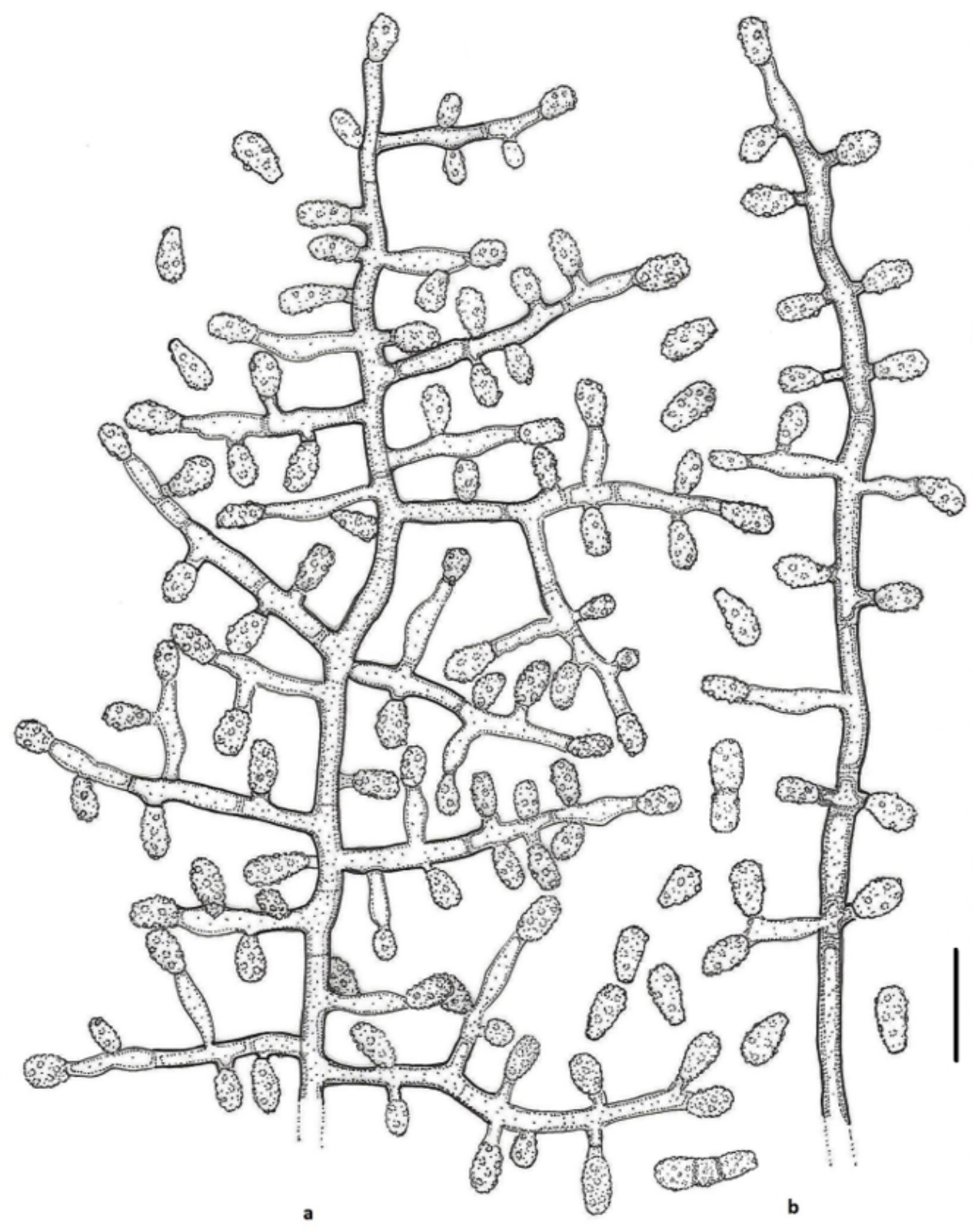

Figure 7

Line drawing of micromorphology of Keratinophyton straussii (BiMM-F78). a, b Conidiophores with young and mature aleurioconidia on PDA (14 days old). a Branched conidiophore. $b$ Unbranched conidiophore with sessile aleurioconidia. Bar $=10$ $\mu \mathrm{m}$ 

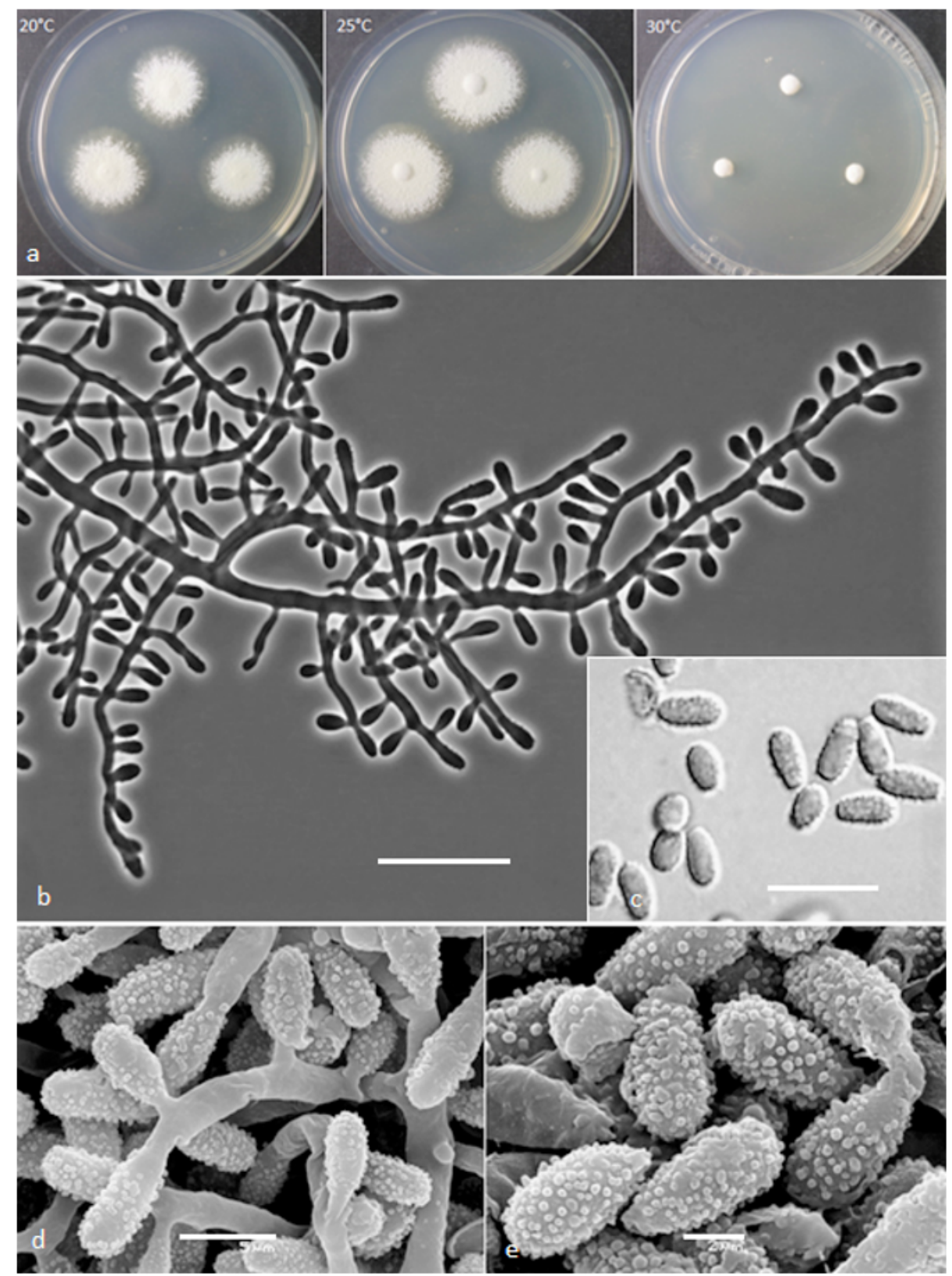

\section{Figure 8}

Keratinophyton wagneri (BiMM-F77). a Colonies on PDA (after 14 days) at $20^{\circ} \mathrm{C}, 25^{\circ} \mathrm{C}$ and $30{ }^{\circ} \mathrm{C}$. b Conidiophores with aleurioconidia. c Aleurioconidia (on PDA, after 14 days). d, e Scanning electron microscopy (SEM) of conidiogenous cells and aleurioconidia (on PDA, after 14 days). Bars $=20 \mu \mathrm{m}$ (b), $10 \mu \mathrm{m}$ (c), $5 \mu \mathrm{m}$ (d), $2 \mu \mathrm{m}$ (e) 


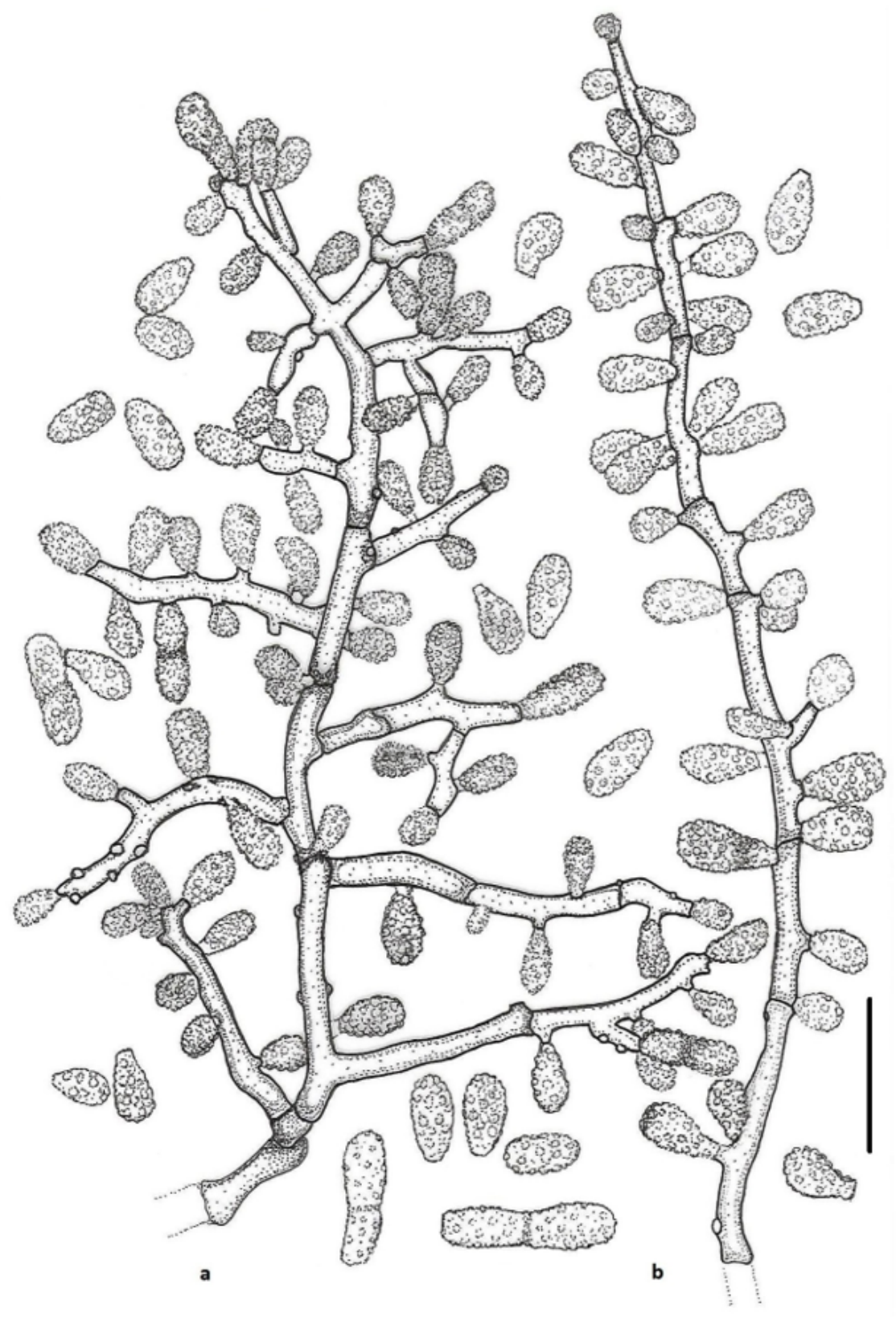

Figure 9

Line drawing of micromorphology of Keratinophyton wagneri (BiMM-F77). a, b Conidiophores with young and mature aleurioconidia on PDA (after 14 days). a Branched conidiophore. $b$ Unbranched conidiophore with sessile aleurioconidia. Bar $=10$ $\mu \mathrm{m}$ 


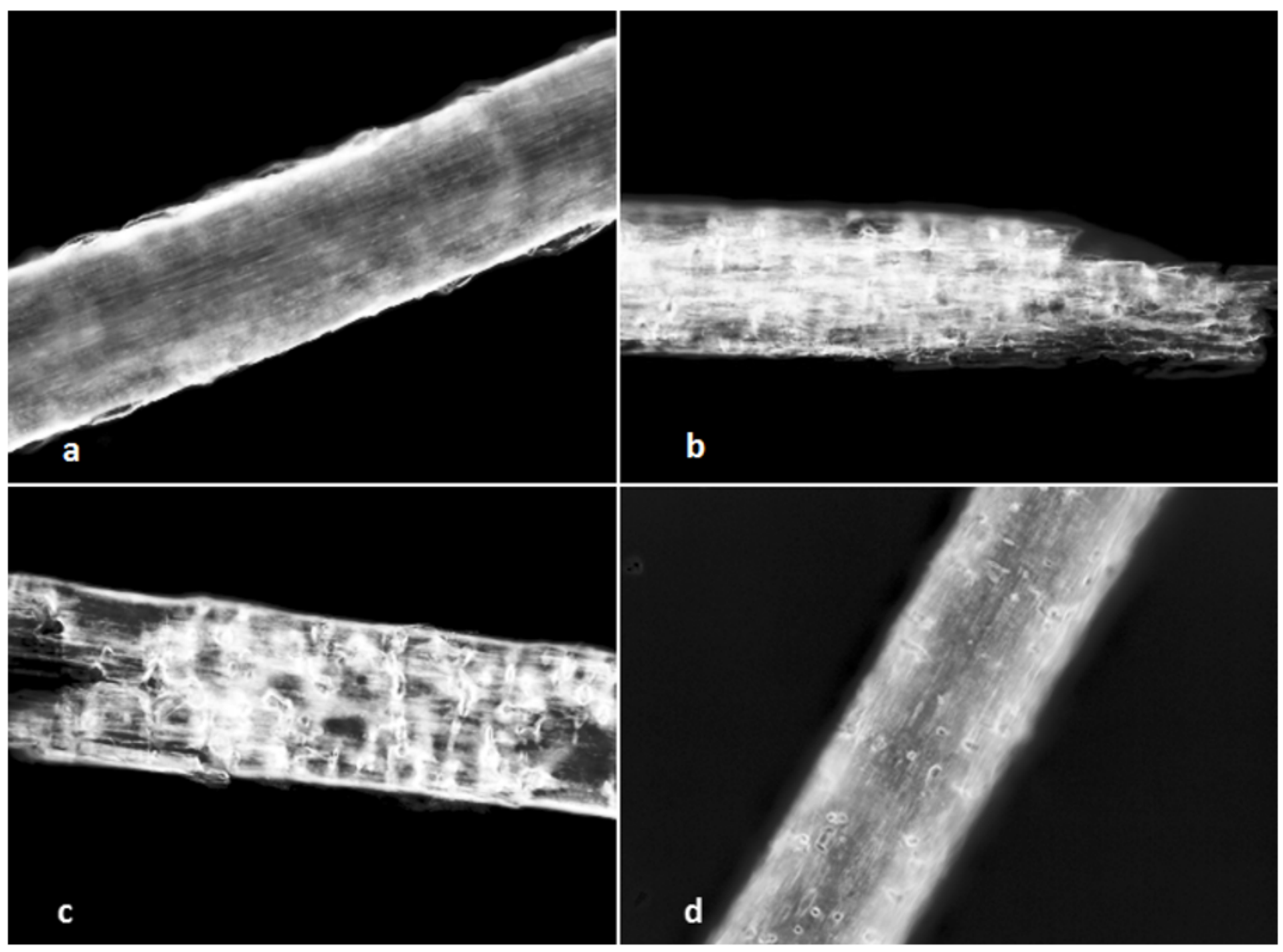

\section{Figure 10}

Hair perforation in vitro - keratinolysis. A detail view on a child hair after colonization by the fungus on PDA (after 21 days) at 25 ${ }^{\circ} \mathrm{C}$. a Keratinophyton lemmensii (BiMM-F76). b Keratinophyton gollerae (BiMM-F250). c Keratinophyton straussii (BiMM-F78). d Keratinophyton wagneri (BiMM-F77). Intensity of attack on the hair was estimated on a scale of 0 to 4 (Marchisio et al., 1994). a 0-1 = light attack to cuticle. b, c 4 = cuticle and cortex attack with about $80 \%$ destruction. $\mathrm{d} 2=$ cuticle and cortex attack with about $20 \%$ destruction. 